\title{
On the Impact of Case and Prosody on Thematic Role Disambiguation: An Eye-Tracking Study on Hungarian
}

Language and Speech 202I, Vol. 64(4) 930-96I (C) The Author(s) 2020

(c) (1) $\$$

Article reuse guidelines: sagepub.com/journals-permissions DOI: I0.I I77/0023830920974709 journals.sagepub.com/home/las

\author{
Gábor Müller
}

Bielefeld University, Germany

\section{Emese Bodnár}

Georg-August-University Göttingen, Germany;

University of Debrecen, Hungary

\section{Stavros Skopeteas \\ Bielefeld University, Germany; \\ Georg-August-University Göttingen, Germany}

\section{Julia Marina Kröger}

Bielefeld University, Germany

\begin{abstract}
Thematic-role assignment is influenced by several classes of cues during sentence comprehension, ranging from morphological exponents of syntactic relation such as case and agreement to probabilistic cues such as prosody. The effect of these cues cross-linguistically varies, presumably reflecting their language-specific robustness in signaling thematic roles. However, language-specific frequencies are not mapped onto the cue strength in a one-to-one fashion. The present article reports two eye-tracking studies on Hungarian examining the interaction of case and prosody during the processing of case-unambiguous (Experiment I) and case-ambiguous (Experiment 2) clauses. Eye fixations reveal that case is a strong cue for thematic role assignment, but stress only enhances the effect of case in case-unambiguous clauses. This result differs from findings reported for Italian and German in which case initial stress reduces the expectation for subject-first clauses. Furthermore, the sentence comprehension facts are not explained by corpus frequencies in Hungarian. After considering an array of hypotheses about the roots of cross-linguistic variation, we conclude that the crucial difference lies in the high reliability/availability of case cues in Hungarian in contrast to the further languages examined within this experimental paradigm.
\end{abstract}




\section{Keywords}

Thematic roles, ambiguity, focus, prosody, eye tracking, Hungarian

\section{Introduction}

Thematic role assignment is an essential part of sentence comprehension. Several morphosyntactic cues, such as case, person/number agreement and linearly determined argument positions, encode syntactic functions (e.g., subject and object) that are mapped onto thematic roles (e.g., agent and patient) in conjunction with the valency of the verbal head. Another array of cues, such as animacy, contextual properties, and prosodic structure motivate inferences about thematic roles, based on regularities in discourse. The present article examines the interplay between case and prosody in thematic role disambiguation in Hungarian by means of two eye-tracking experiments (case-unambiguous and case-ambiguous noun phrases (NPs)). Case is a reliable cue for syntactic functions in an agglutinative language such as Hungarian. The role of prosody is less straightforward, but it has been shown to influence thematic role disambiguation in various languages, including Hungarian.

The contribution of prosody to syntactic processing is manifold (Carlson, 2009; Cutler et al., 1997). Prosodic prominence attracts attention and facilitates speech processing (Cutler \& Foss, 1977). Pitch accents and boundary tones are informative for prosodic phrasing, reflecting properties of the constituent structure (Fodor, 1998). Crucially, several studies show that prosody contributes to the disambiguation of thematic role ambiguities (Carlson, 2009). But, how does prosody contribute to thematic-role assignment? To the exception of some tonal languages such as Massai that express case through tone (Dryer, 2013), prosodic events do not signal particular syntactic functions, but rather they depend on the interplay of constituency and information structure (Féry, 2017; Ladd, 2008). Since topics and foci correlate with syntactic functions in discourse, it is reasonable to examine the question whether the impact of prosody on thematic role assignment is mediated by information structure.

Empirical research on the relationship between information structure and syntactic functions has discovered two apparently contradictory trends, namely the "focus-to-object" and the "topicto-object" mapping. Studies on speech comprehension show that initial foci are mapped onto objects. Weber et al. (2006b) compare two prosodic structures of German main clauses with caseambiguous initial arguments. They report that if the nuclear stress falls on the verb, the initial (nonfocal) NP is interpreted as a subject such that anticipatory fixations are directed more frequently towards the patient than towards the agent character. However, when the initial NP is stressed, anticipatory gazes to the agent increase, indicating that the stressed initial NP is more frequently interpreted as an object. Grünloh et al. (2011) compared German case-marked and case-ambiguous transitive clauses with two intonational patterns: a flat intonational pattern; a prosodic structure with a high pitch accent within the stressed syllable of the initial NP (that signals focus in German). A first experiment shows that initial sentence stress enhances the processing of case-marked OVS sentences (German speaking children, average 4-10 years old). In a second experiment, the initial focus was supported by an appropriate context (involving contrast). The findings show that the contrastive interpretation of the initial NP (supported by the context and the prosodic realization) enhances its interpretation as an object. Read et al. (1980) report another result mapping focus to objects in globally ambiguous $w h$ - questions in Dutch. When the non-wh-argument of a case ambiguous question is de-accented, it is more likely interpreted as a subject than when it is accented. In these studies, the stressed NP is mapped onto an object constituent, suggesting a "focus-toobject" inference in sentence comprehension. In terms of information structure, this mapping is not 
surprising, since typically subjects are the topic of the utterance while objects belong to the focused partition (Du Bois, 2003; Lambrecht, 2000).

A further line of research reports a correlation between fronted objects and topics. Kaiser and Trueswell (2004) track the eye gaze behavior of Finnish speakers and report that initial subjects are contextually unrestricted, while initial objects invoke anticipatory looks to a new referent. Weskott (2003) shows that German object-first sentences are easier to process if the object contains given information (Experiment 3). Experiments with prosodic manipulations show that the subject-first preference (i.e., the expectation of an unmarked $\mathrm{SV}(\mathrm{O})$ order), is reduced through contrastive stress on clause-final arguments in Italian and German (Bates et al., 1982; MacWhinney et al., 1984). The implication of these findings is a "topic-to-object" mapping, which can also be theoretically motivated: whenever the given-first principle applies (Chafe, 1976; Clark \& Haviland, 1977), the expectation of a subject-first bias decreases.

The contradiction between the "focus-to-object" and the "topic-to-object" mapping is only apparent. The results of these studies imply that the information structural functions (topic and focus) are not associated with syntactic functions (subject and object) in a one-to-one relationship. The languages at issue have a subject-first preference that applies across contexts. Focusing or topicalization are discourse triggers that license optional constituent fronting, in other words a deviation from the preferred order. Whenever a focus or a topic is encountered at the beginning of the utterance (either established through the context or signaled by prosody), the comprehender assumes that a deviation from the otherwise preferred subject-first order is contextually licensed. This view fits better to the data, since the available empirical findings involve a reduction of the subject-first bias when the initial argument is either a topic or a focus, and not necessarily that an object-first order is preferred over a subject-first order.

This reasoning is expected to apply to any language that shares these properties: subject-first preference in word order; left peripheral positions for topics and foci. However, some puzzling findings are reported for Hungarian, which has exactly this typological profile. MacWhinney et al. (1985) examined clauses with object NPs without an accusative suffix (which is not grammatical in Hungarian). They compared pragmatically neutral sentences to sentences with a preverbal focus and found that $\mathrm{N}_{\mathrm{FOC}} \mathrm{VN}$ comes with an $\mathrm{SVO}$ bias, while $\mathrm{NN}_{\mathrm{FOC}} \mathrm{V}$ has a bias towards OSV; in both cases, the focus is mapped onto the subject and not onto the object - as expected. The challenging question is why cross-linguistic differences appear in an inference from information structure to thematic-role assignment.

The first aim of the present study is to examine the effects of case marking and prosodic prominence in on-line comprehension, by means of eye-tracking data that provide incremental evidence about speakers' expectations through anticipatory eye fixations. The effects of these cues will be first examined in case-unambiguous clauses (Experiment 1); in a second study we shall examine the role of prosody in the disambiguation of locally ambiguous clauses (Experiment 2). Since previous studies report that prosodic cues have unexpected effects in Hungarian (MacWhinney et al., 1985), we need to examine word order preferences in discourse, since preferences in speech comprehension may reflect particular discourse preferences in this language.

The relevant grammatical aspects of Hungarian are outlined in Section 2. Section 3 presents a corpus study on left peripheral arguments in focus and topic positions examining the likelihood of subjects and objects in order to clarify which expectations may be motivated by regularities in discourse. Based on this background, we examine the effects of case and prosody in two eyetracking studies. The first study establishes the effects of case and prosody on the comprehension of unambiguous clauses; see Section 4. The second study examines whether prosody has an influence on the anticipatory eye gaze behavior in locally ambiguous clauses; see Section 5 . The results of the experiments are generally in line with the findings reported in MacWhinney et al. (1985). 
The relevance of our results as well as their consequences for understanding the interaction of thematic role cues are discussed in Section 6.

\section{Hungarian: grammatical background}

This section outlines the relevant aspects of Hungarian grammar focusing on accusative case marking, word order, and prosodic structure. In Hungarian, nominative case is expressed by a zero exponent, which means that there is a markedness asymmetry between the unmarked nominative case and further cases marked by suffixes. Accusative case is coded by the suffix - $t$ "ACC," compare $(1 \mathrm{a}-\mathrm{b})$, whereby a thematic vowel (a/á/e/é/o/ö) may be added depending on the stem vowels. While the thematic vowel is not restricted to accusative case (it is not a reliable cue for case), the suffix - $t$ is a highly reliable cue, since it remains constant across nouns in accusative case. Omission of the accusative suffix generally leads to ungrammaticality; see (1b). It can only be omitted in limited environments, in particular after the possessive suffixes of the 1st and 2nd person singular (Dékány, 2017). Possessed NPs without an accusative suffix give rise to local ambiguities, since nominative possessed NPs have the same form as accusative possessed NPs with dropped suffix; see (1c) and (1d). This ambiguity has been used in studies on thematic role disambiguation in Hungarian (MacWhinney \& Pléh, 1997; MacWhinney et al., 1985).

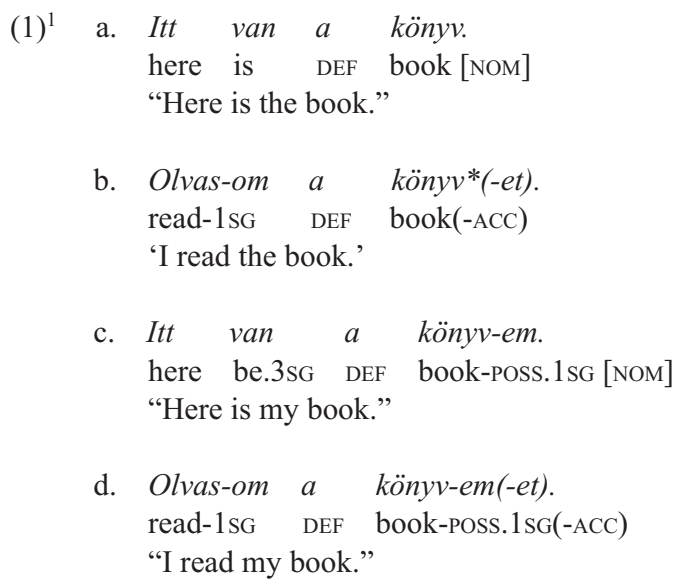

Hungarian is a language with a relatively flexible word order. The most extensive corpus study on Hungarian word order is reported by Kas et al. (2016), based on the Hungarian National

Table I. Word order frequencies (Kas et al., 2016, p. 369).

\begin{tabular}{lrr}
\hline Word order & \multicolumn{2}{l}{ n } \\
\hline Subject-Verb-Object & 507,759 & 38.4 \\
Subject-Object-Verb & 374,178 & 28.3 \\
Object-Verb-Subject & 157,031 & 11.9 \\
Object-Subject-Verb & 117,373 & 8.9 \\
Verb-Subject-Object & 98,015 & 7.4 \\
Verb-Object-Subject & 68,739 & 5.2 \\
Total & $1,323,095$ & 100 \\
\hline
\end{tabular}


Corpus (Oravecz et al., 2014). The word order frequencies in Table 1 reveal a general preference for subjects to precede objects in discourse: with V-medial configurations, SVO is $(507,759 / 157,031=) 3.2$ times as likely as OVS, with V-final clauses SOV is $(374,178 / 117,373$ $=) 3.2$ times as likely as OSV, and with V-initial clauses VSO is $(98,015 / 68,739=) 1.4$ times as likely as VOS. These frequencies are in line with the subject-first bias in V-medial and V-final clauses that is reported by previous studies on Hungarian sentence comprehension (MacWhinney et al., 1985; Pléh, 1981).

The basic word order of Hungarian is VSO; see illustration in (2a). Postverbal arguments are underspecified for information structure, while preverbal arguments either occupy the focus or the topic position (É. Kiss, 1998, 2008; Surányi, 2010). Hence, despite their frequency in discourse (Table 1), word orders with preverbal arguments are not pragmatically neutral and therefore analyzed as derived orders. The focus position is immediately preverbal and can host subjects, objects, further arguments or adjuncts; see illustration in (2b) for subjects. Foci attract the finite verb, such that the verbal particle ( $k i$ "out" in the examples below) is stranded in the postverbal domain. ${ }^{2}$ Topics are sentence-initial (topics can only precede foci if both types of left-peripheral configuration are available). The distinction between focus and topic is reflected in the linearization of the particle and the verb (É. Kiss, 1998). While the particle follows the verb in the focus construction in $(2 \mathrm{~b})$, it precedes the verb in the topic construction in $(2 \mathrm{c})$.
a. Ki-nyit-ott-a János a könyv-et.
out-open-PST-3SG.DEF János DEF book-ACC
"János opened the book."
b. [János $]_{\mathrm{FOC}}$ nyit-ott-a ki a könyv-et. János open-PST-3SG.DEF out DEF book-ACC
"JÁNOS opened the book."
c. $[\text { János }]_{\mathrm{TOP}}$ ki-nyit-ott-a a könyv-et. János out-open-PST-3SG.DEF DEF book-ACC
"As for János, he opened the book."

The examples in (2) demonstrate that the order of the verb and the verbal particle offers an unambiguous cue for the discourse function of the left peripheral constituent. A further correlated cue is the placement of the nuclear accent. Hungarian is a language with initial prominence at different levels of the prosodic constituency. At the word level, word stress generally falls on the first syllable (to the exception of some phrasal compounds; Varga, 2002). At the sentence level, prosodic prominence is always initial within the phonological domain of an intonational phrase. In the absence of left peripheral constituents, the left edge of the intonational phrase encompassing the predicate is aligned with the verb or the verbal particle (if available), which thus bears the nuclear stress of the clause, as in (3a). A left-peripheral focus phrase is part of the intonational phrase that encompasses the predicate and bears the intonational nucleus; see (3b). Topic phrases crucially differ: they form an intonational phrase on their own, while the comment is encompassed by a separate intonational phrase; see (3c). Both intonational phrases have a phonological head (a stress on the first syllable), while the nuclear stress of the sentence falls on the intonational phrase of the predicate, in other words, on the verb (Szendröi, 2001, 2003; Varga, 2002). Crucially, the discourse function of left peripheral constituents (topic or focus) is unambiguously expressed by the placement of nuclear accent and equally applies to whatever constituent (subjects, objects or further arguments and adjuncts). 


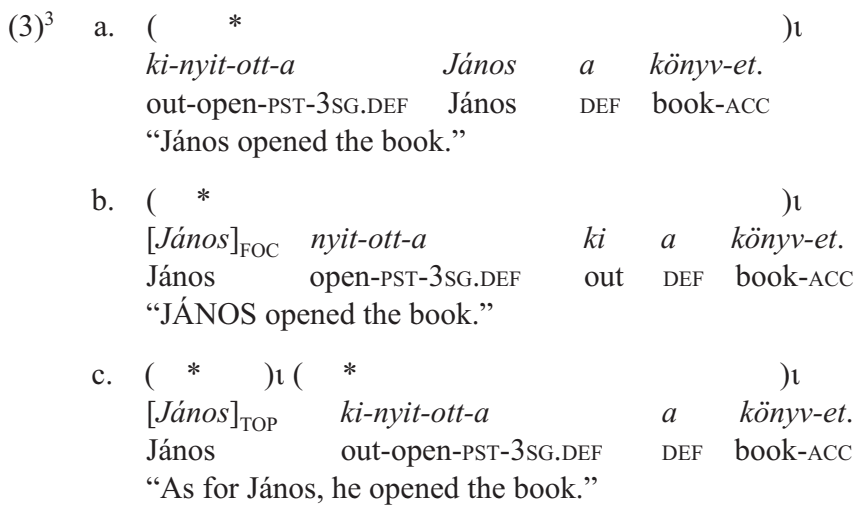

Summing up, the following grammatical properties of Hungarian will be relevant for interpreting the role of case, prosody and order in speech comprehension:

(4) a. Reliability/availability of case cues

The case cues are highly reliable (constant across nouns) and almost always available - to the exception of limited constructions as in $(1 \mathrm{c}-\mathrm{d})$.

b. Bias for subject-initial orders

Subject-initial orders are more likely than object-initial orders; see Table 1.

c. Nuclear stress and focus

If the nuclear stress of the prosodic domain encompassing the predicate falls on a left peripheral constituent, this constituent is focused; see (3b).

\section{Left peripheral arguments in corpus}

The findings in various languages that an initial focus reduces the subject-first bias in speech comprehension (see summary in Section 1) can be accounted for by the cross-linguistic preference for subjects to serve as the topic of the utterance (Du Bois, 2003; Lambrecht, 2000). Since speech comprehension studies on Hungarian report a subject bias for foci (MacWhinney et al., 1985), it would be interesting to know whether this phenomenon relates to particular preferences in discourse. Hungarian distinguishes topics and foci by morphosyntactic means - as seen in (2) - which offers the possibility to identify the discourse function of left peripheral constituents. The cross-linguistic preferences predict a subject-bias for left peripheral topics in comparison to left peripheral foci. In order to test whether the speech comprehension facts reflect some discourse preferences that are particular to Hungarian, we examined left peripheral configurations in clauses with a transitive verb and two overt arguments-as in (5) - in the Hungarian National Corpus (Oravecz et al., 2014).

(5) Discourse function of the left peripheral argument $\left(\mathrm{NP}_{1}\right)$
a. Topic: $\left[\mathrm{NP}_{1}\right]_{\text {TOP }}$ Part $\mathrm{V} \mathrm{NP}_{2}$; cf. (2c)
b. Focus: $\left[\mathrm{NP}_{1}\right]_{\text {FOC }}$ V Part $\mathrm{NP}_{2}$; cf. (2b)

We extracted the configurations illustrated in (5) with the 24 transitive verbs that were used in the experimental studies presented in Section 4 in order to draw inferences about the expected 
behavior in the eye-tracking studies. The corpus queries contained combinations of the 24 verbs in the 3 rd person singular (present and past) with verbal particles. The sample targeted 20 tokens of the particle $+\mathrm{V}$ order in (5a) and 20 tokens of the $\mathrm{V}+$ particle order in $(5 \mathrm{~b})$ for each verb. The examined dataset is restricted to main declarative affirmative clauses (hence, excluding imperatives and interrogatives, and clauses with negation). We queried combinations of each verb with several particles, starting with the most frequent particles and proceeding with less frequent particles up to collecting $20+20$ tokens exhibiting the properties in (5). The basis was the list of particles by H. Tóth and Patloka (2009), sorted by their frequency in the Hungarian National Corpus ( $n$ in million tokens; queried on June 15, 2018): meg "PFV" (3.86) > el "away" (2.53) > ki "out" $(2.00)>f e l(1.26)$ "up" > be "in" (1.24) > le "down" $(0.72)>$ vissza "back" $(0.36)>$ össze $(0.28)$ "together" > bele "into" $(0.14)>$ végig "through" $(0.05) .{ }^{4}$ The valid sentences were annotated for the syntactic function (subject/object) of the preverbal NP; see examples in (6).

(6) Discourse function of the left peripheral argument $\left(\mathrm{NP}_{1}\right)$

a. $\mathrm{NP}_{1}$ topic and subject

$\begin{array}{lll}\text { a mamá-juk } & \text { meg-véd-i } & \text { ök-et } \\ \text { DEF mom-POSS.3PL[NOM] } & \text { PFV-protect-3SG } & \text { 3PL-ACC } \\ \text { "their mom protects them" } & & \end{array}$

b. $\mathrm{NP}_{1}$ topic and object

$\begin{array}{llll}\text { pár-já-t } & \text { meg-véd-i } & a z & \text { állat } \\ \text { partner-POSS.3SG-ACC } & \text { PFV-protect-3SG } & \text { DEF } & \text { animal [NOM] }\end{array}$

"the animal protects his partner"

c. $\quad \mathrm{NP}_{1}$ focus and subject

$\begin{array}{llllll}\text { egy új-abb } & \text { csoda-gyerek } & \text { büvöl-i } & \text { el } & a & \text { sakk-világ-ot } \\ \text { INDEF new-CMPR } & \text { wonder-child [NOM] } & \text { fascinate-3SG } & \text { away } & \text { DEF } & \text { chess-world-ACC }\end{array}$

"a NEWER PRODIGY fascinates the world of the chess"

d. $\quad \mathrm{NP}_{1}$ focus and object

\begin{tabular}{|c|c|c|c|}
\hline $\begin{array}{l}\text { politikus } \\
\text { politician }\end{array}$ & $\begin{array}{ll}\text { portré-já- } t & \text { fest- } i \\
\text { portrait-POSs.3sG-ACC } & \text { paint-3SG }\end{array}$ & $\begin{array}{l}\text { meg } \\
\text { PFV }\end{array}$ & $\begin{array}{l}a \\
\mathrm{DEF}\end{array}$ \\
\hline
\end{tabular}

"the artist paints THE PORTRAIT OF THE POLITICIAN"

The targeted total of 20 valid tokens was not reached with all 24 verbs (four verbs in the condition with a preverbal topic and nine verbs in the condition with a preverbal focus had less than 20 valid tokens; furthermore, the verb sprézi "sprays" does not occur with particles in the corpus). The results of the corpus study are presented in Table 2, showing that the discourse function (topic vs. focus) has an impact on the relative frequency of syntactic functions: objects are more likely in the focus position $(24.0 \%)$ than in the topic position (10.4\%).

A generalized linear mixed-effects model on the likelihood of left peripheral objects (contrast coded as: $0=$ subject, $1=$ object) with discourse function as fixed factor (contrast coded as: $0=$ topic, 1 = focus) and the verb stems as random factor (intercept and slope with the fixed factor) reveals that the impact of Discourse Function is significant. The model of maximal fit has a significant intercept, $\beta=-2.7$; standard error $(S E)=0.37 ; z=-7.2 ; p<0.001$, reflecting the fact that subjects are more likely than objects in the left periphery (either as topics or as foci). DiSCOURSE FUNCTION has a positive effect, revealing that objects are more frequent in the level of interest (focus) than in the zero-coded baseline (topic), $\beta=1.2 ; S E=0.53 ; z=2.2 ; p<0.05$. A comparison between a model with DisCOURSE FunCTION as a fixed factor (Akaike information criterion (AIC) $=$ 611.6) and a model without fixed factor $(\mathrm{AIC}=614.4)$ reveals that the former model offers a significantly better fit on the data than the latter, log-likelihood test (LLT): $\chi^{2}=4.8, p<0.05 .{ }^{5}$ Hence, 
Table 2. Subject/object frequencies and left peripheral positions.

\begin{tabular}{|c|c|c|c|c|c|c|}
\hline & \multicolumn{2}{|c|}{ Subject } & \multicolumn{2}{|c|}{ Object } & \multicolumn{2}{|c|}{ Total } \\
\hline & $n$ & $\%$ & $n$ & $\%$ & $n$ & $\%$ \\
\hline Topic & 378 & 89.6 & 44 & 10.4 & 422 & 100.0 \\
\hline Focus & 263 & 76.0 & 83 & 24.0 & 346 & 100.0 \\
\hline Total & 641 & 83.5 & 127 & 16.5 & 768 & 100.0 \\
\hline
\end{tabular}

object fronting is significantly more likely with left peripheral foci than with topics, taking the random effect of different verbs into account.

In sum, the corpus frequencies confirm the general bias for initial subjects in XVY orders (see SVO vs. OVS in Table 1) and show that object fronting is more likely with foci than with topics. Hence, if information structure influences thematic role assignment during speech comprehension, the corpus frequencies predict the following bias, that may modulate the general preference for subject-initial orders in (4b):

(7) "Focus-to-object" bias

A left peripheral focus is 2.3 times as likely as a left peripheral topic to be an object; see Table 2 .

\section{Experiment I: case and stress}

Experiment 1 examines whether case and prosody have an effect on processing thematic roles in Hungarian. This experiment should establish the effects of sentence comprehension on eye gaze behavior with case-unambiguous sentences.

\section{I Method}

4.I.I Participants. Twenty-four monolingual native Hungarian adults participated in the experimental study (18 females, six males; age range: 19-29 years; average 22.2; all right-handed; either uncorrected vision or corrected to normal, no sight impairments; speakers with prior knowledge of psycholinguistics research methods were excluded). Recordings took place at the University of Debrecen, Hungary. Participants freely offered informed consent (written) and were paid 3000 Hungarian Forint for their participation.

4.I.2 Material. The visual material was adopted from Kröger (2019), who used clipart images to assemble simple scenarios in a series of studies within the visual-world paradigm. All scenes contained three animal characters (see Figure 1), whereby two of them performed identical actions affecting their neighboring character (see Knoeferle et al., 2005 for a previous study with this experimental manipulation). Hence, the middle character was involved in two events (as agent and patient, respectively), while the two peripheral characters were involved in a sole event, either as agents or as patients. All experimental prompts started with the middle character, which is ambiguous between an agent and patient role; see (8). After mentioning the ambiguous character, the peripheral characters are possible targets (see Knoeferle et al., 2005 and Kröger, 2019 for previous studies with the same manipulation). The choice of a target depends on the cues for thematic role disambiguation. For instance, when comprehending an SVO sentence, the target after processing the subject was the patient character (character on the left in Figure 1), while in OVS sentences, the 


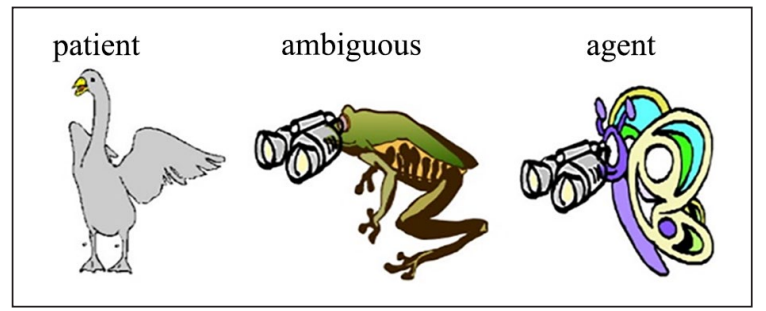

Figure I. Visual stimulus (left-mirrored).

Table 3. Factorial design of experiment I (underlined: nuclear stress are underline).

\begin{tabular}{lll}
\hline Factors & & Conditions \\
\hline Case & Stress & \\
$N_{\text {NOM }} \cdots$ & $\underline{N P} \vee N P$ & Subject-Verb-Object \\
$N P_{\text {ACC }} \cdots$ & $\overline{N P} \vee N P$ & Subject-Verb-Object \\
& $\overline{N P} \underline{V} \underline{N P}$ & Object-Verb-Subject \\
\hline
\end{tabular}

target was the agent. This design offers on-line evidence for the thematic role assignment that the comprehenders assume at the critical time region (Knoeferle et al., 2005). In the stimuli design, we avoided situations with stereotypical connections between animals (e.g., cat and mouse) or between animals and actions (e.g., dog and barking). In order to outbalance the effect of left-right asymmetries, two series of the same pictures (left-mirrored and right-mirrored) were used in the experimental sessions. This stimulus design differs from designs that involve a distractor character that is excluded by the selectional properties of the verb (see, e.g., Sauppe, 2016).

The experiments were based on a $2 \times 2$ factorial design with the factors CASE and STRESS. The factor CASE had two levels depending on the case marking of the initial NP: nominative-first $\left(\mathrm{NP}_{\mathrm{NOM}}\right.$ $\left.\mathrm{V} \mathrm{NP}_{\mathrm{ACC}}\right)$ and accusative-first $\left(\mathrm{NP}_{\mathrm{ACC}} \mathrm{V} \mathrm{NP}_{\mathrm{NOM}}\right)$. The factor STRESS had equally two levels, clauseinitial stress and neutral stress. The permutation of these levels leads to four experimental conditions (Table 3).

The presented utterances contained an initial NP, a verb and a temporal adverb followed by a second NP. The factor CASE was implemented by the case of the NPs, as illustrated in (8). The use of postverbal adverbs offers the possibility to test the impact of the verb on anticipatory fixations and has been used in a large paradigm of previous studies (Kamide et al., 2003; Knoeferle et al., 2005; Kröger, 2019; Kröger et al., 2017; Münster, 2016; Sauppe, 2016; Weber et al., 2006b). We used temporal adverbs (manner adverbs preferably precede the verb in Hungarian) that are compatible with present tense, referring to a time point that is either simultaneous (present) or following (future) the utterance time in Hungarian (Rounds, 2001). Our experimental sentences did not contain verbal particles, such that prosodic prominence was the only available cue for the discourse function of the initial NP; see illustration in (8) and full list of the items in Appendix A.

a. $\quad \mathrm{NP}_{\mathrm{NOM}} \mathrm{V} \mathrm{NP}_{\mathrm{ACC}}(\mathrm{SVO})$

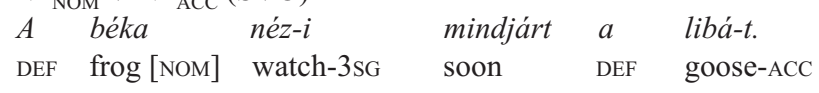

"The frog watches soon the goose." 
b. $\mathrm{NP}_{\mathrm{ACC}} \mathrm{V} \mathrm{NP}_{\mathrm{NOM}}(\mathrm{OVS})$

$\begin{array}{lllll}A & \text { béká- } t \text { néz-i } & \text { mindjárt } & \text { a lepke. } \\ \text { DEF frog-ACC watch-3SG soon } & \text { DEF } & \text { butterfly [NOM] } \\ \text { "The butterfly watches soon the frog." } & & \end{array}$

The factor STRESS was implemented through the prosodic realization of the stimuli. Recordings of the audio stimuli were conducted in the recording studio of the Bielefeld University with a 22-year old female native speaker of Hungarian speaking into a microphone, while picture scenes and the accompanying descriptions were presented to her remotely using Keynote. The speaker was instructed to make a small pause in between words of the utterance and to avoid listing intonation. Recordings were made at a sampling rate of $48 \mathrm{kHz}$ and were saved in .wav files.

The experimental material contained utterances with intonational nucleus on the verb (NP V NP) and utterances with intonational nucleus on the initial NP (NP V NP); see Table 3. The fundamental frequency (F0)-excursion of an SVO sentence is illustrated in Figure 2. Figure 2 in the left panel illustrates the nuclear stress on the verb, which corresponds to the default prosodic realization of a Hungarian utterance (Genzel et al., 2015): the subject is a topic with a rising contour, while the nuclear stress on the verb is realized with a sharp rise early within the initial syllable followed by a falling contour; see phonological structure in (3c) in Section 2. In the right panel, the fall is realized within the initial syllable of the preverbal constituent indicating that it is in the focus position; see (3b) in Section 2. In both pitch tracks, the postnuclear domain is deaccented, which is in line with the findings of prosodic studies on Hungarian, showing that deaccenting (optionally) occurs either after a narrow focus or after the nuclear stress of a broad focus domain with differences in frequency (Genzel et al., 2015; Mády, 2012, 2015). In order to enhance the distinction between word regions in the stimuli, a 300 milliseconds (ms) pause was inserted after every prosodic word resulting in a slightly fragmented speech sound.

The F0-excursions illustrated in Figure 2 were consistently used in the recordings, as shown by the median values of the entire stimulus set in Figure 3. Pitch measurements were obtained from the sound files by means of a Praat (Boersma \& Weenink, 2019) script written by the authors, which extracted the timing of onsets and offsets of each word and average F0-values of five equal

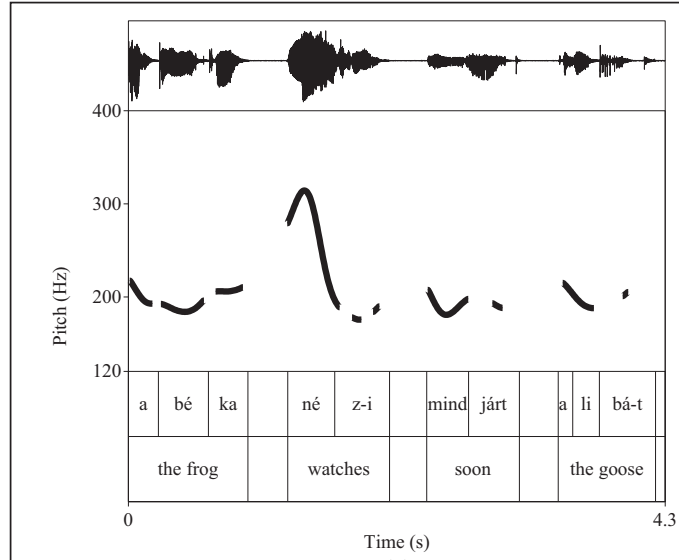

(a)

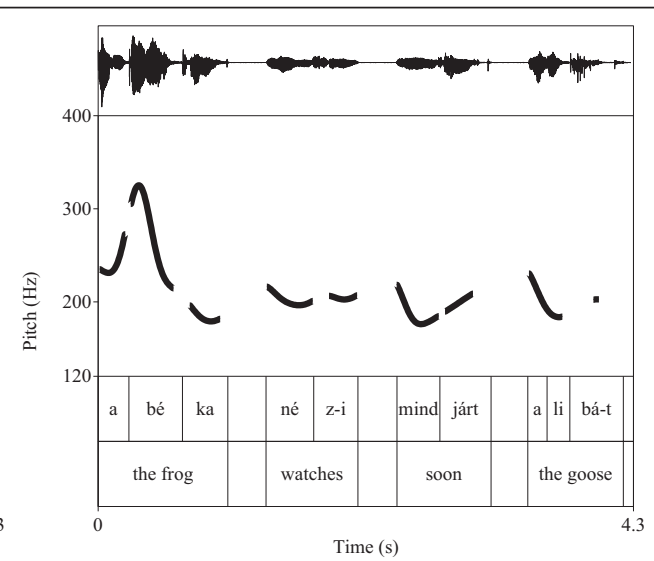

(b)

Figure 2. Illustrative fundamental frequency (F0)-excursions; see morphemic transcription in (8): (a) SVO; (b) SVO. 


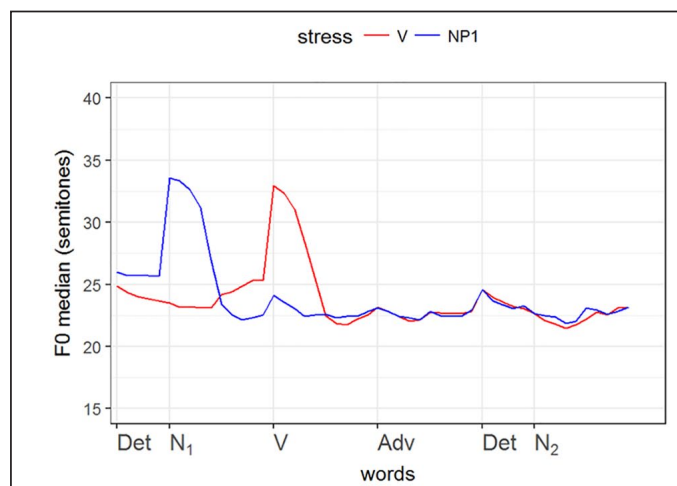

(a)

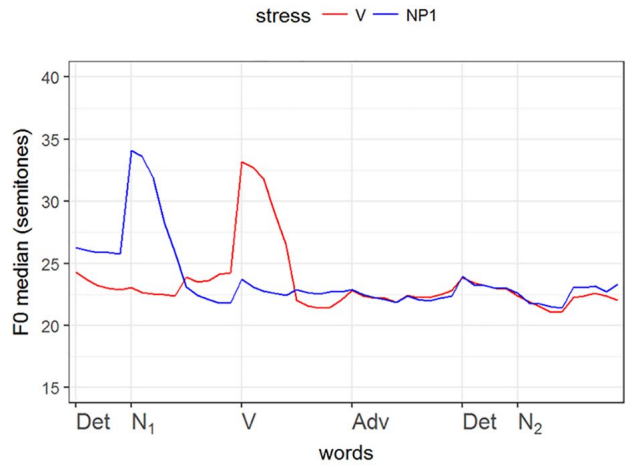

(b)

Figure 3. Median fundamental frequency (FO)-excursions of the stimuli (Experiment I): (a) SVO; (b) OVS.

intervals for each syllable. The $\mathrm{F} 0$-values in $\mathrm{Hz}$ were converted into semitones with a reference value of $50 \mathrm{~Hz}: f_{\text {semitones }}=12\left(\log _{2} f_{\mathrm{Hz}} / 50\right)$ (Grice et al., 2007; Nolan, 2003). Each excursion in Figure 3 presents the median values of the stimuli recorded for an experimental condition (24 items). In order to observe the intonational properties across words of different syllabic length, Figure 3 only presents the F0-values of the first and the last syllable of the lexical categories (nouns, adverbs, and verbs). The pitch excursion of stressed syllables is very similar; depending on the level of STRESS the nuclear accent is realized within the stressed syllable of the initial NP or within the stressed syllable of the verb. In sum, the prosodic patterns of the stimuli reflect the crucial properties of Hungarian intonation, as reported in the available prosodic studies, performed with particular clarity under laboratory conditions.

The F0-values in Figure 3 show that the prosodic realization of the stimuli is highly consistent. Their prosodic properties correspond to the prosodic realization of Hungarian utterances as reported in speech production: topics are mostly deaccented, foci almost always bear a falling accent, while the verb is almost always deaccented after an initial focus (Mády, 2015). Deaccenting of topics is one among the possible realizations of initial topics, while the presence of a falling accent at the initial syllable of the verb following a topic phrase is the dominant pattern in speech production data (Genzel et al., 2015). Hence, these stimuli represent the prosodic effects of information structure in careful speech, certainly having less variation than spontaneous realizations. The consistent realization is expected to enhance the comprehension of the assumed discourse function (topic vs. focus).

The duration means (Appendix B) reveal some variation between conditions: (a) the average duration of subjects (nominative) is shorter than the average duration of objects (accusative), since the former are bare stems and the latter have an accusative suffix; compare duration of $\mathrm{NP}_{1}$ in $\mathrm{SVO}$ versus OVS and SVO versus OVS; (b) the average duration of focused $\mathrm{NP}_{1}$ is longer than the duration of non-focused $\mathrm{NP}_{1}$; compare SVO versus SVO, OVS versus OVS, XVS versus XVS in Appendix B. Effects of focus on duration are known from studies on various languages; see, for instance, English (Eady et al., 1986) and German (Féry \& Kügler, 2008). The consequence of these asymmetries for our analysis is that the eye-tracking data must be time-normalized in order to capture the variation between word regions in length (see subsection 4.1.5).

The experimental conditions in Table 3 (SVO, SVO, OVS, and OVS) were implemented in 24 target items (see Appendix A). A further 72 filler trials were included in order to distract 
participants' attention from the purposes of the study (target:filler ratio 1:3), edited in the same way and recorded by the same speaker as the targets. The fillers were organized in three groups of 24 trials each, which varied the type of construction (a group varying the number of animate characters; a group with intransitive verbs and adverbial expressions; a group with ditransitive verbs in various orders). The material was distributed in eight lists, such that each list contained the 72 fillers and 24 target items distributed in a latin-square design (six target items per condition). The lists were separately pseudo-randomized for each session. Altogether we evaluated $(24$ speakers $\times 24$ items =) 576 trials.

4.I.3 Predictions. The critical time region for tracking comprehenders' expectations starts from the time point in which $\mathrm{NP}_{1}$ has been processed and holds until the onset of $\mathrm{NP}_{2}$ (Kamide et al., 2003; Knoeferle et al., 2005). Since case is expressed by suffixes, the case of $\mathrm{NP}_{1}$ can only have reflexes on processing after the offset of $\mathrm{NP}_{1}$, which is followed by a $300 \mathrm{~ms}$ break. Eye movements towards mentioned entities start within a time interval of 100-200 ms (Altmann, 2011; Allopena et al., 1998) after the critical acoustic signal; anticipatory fixations require additional processing which is expected to result in longer latencies. Hence, anticipatory fixations motivated by processing the case of $\mathrm{NP}_{1}$ are roughly expected to appear with the verb onset.

The treatments of this experiment are expected to be informative for the effects of CASE and STRESS. Besides, these effects are interwoven with the word order and information structural biases - as summarized in (4) and (7) - as well as by general asymmetries in the effect of thematic roles in attracting attention. The relations between these effects are discussed in the following.

CASE is highly regular and almost always available in Hungarian — as stated in (4a) — which predicts a strong impact on thematic role disambiguation. The expected effects in the critical time region are straightforward: processing a nominative $\mathrm{NP}_{1}$ is expected to invoke anticipatory fixations on the patient character, while an accusative $\mathrm{NP}_{1}$ should invoke fixations on the agent character. In addition, nominatives and accusatives differ: (a) with respect to morphological markedness; (b) with respect to the range of constructions that are possible with each case.

At the morphological level, the nominative case is the inflectional default, since it is identical to the bare stem in Hungarian - the accusative case is the non-default option, marked by a suffix; see $(1 \mathrm{a}-\mathrm{b})$ in Section 2. The non-default case (accusative) is expected to have a stronger impact on attracting the attention of comprehenders than the default case (nominative) (see Longenbaugh \& Polinsky, 2016).

With respect to the range of possible constructions, an accusative $\mathrm{NP}_{1}$ implies a transitive verb and a nominative argument, while a nominative $\mathrm{NP}_{1}$ can form a complete sentence already with an intransitive verb. Hence, up to the time point that the verb is processed, an initial accusative is expected to have a stronger impact on the visual search for a further argument than an initial nominative. This prediction follows from the view that comprehenders anticipate the minimal possible syntactic structure at each time point in sentence processing (see minimality/distinctness principle in Bornkessel-Schlesewsky \& Schlesewsky, 2009 or "least effort principle" in Fodor, 1998). At the time point that the comprehender has processed the verb, the minimal structure is necessarily transitive, that is, either case of the $\mathrm{NP}_{1}$ predicts the presence of a further argument.

The placement of nuclear stress on the preverbal constituent is a cue for focus; see (4c). Left peripheral foci are more frequently objects than left peripheral topics; see (7). Hence, a stressed initial NP may modulate the expectations from the preferred subject-initial word order in Hungarian. In the critical time region, the expected effect of STRESS is an increase of the fixations to the agent after processing a stressed $\mathrm{NP}_{1}$.

Besides the experimental manipulations, the expected results may be influenced by further factors that have been shown to influence speech comprehension. The preferred word order in 
Hungarian predicts a bias for subject-initial clauses; see (4b). Previous studies on languages with a preference for subject-initial orders have shown evidence for a subject-first bias in comprehension even with case-marked initial accusatives (see German in Kamide et al., 2003).

Finally, agents attract attention in visual depictions of events (Cohn \& Paczynski, 2013) and the preference for fixations to the agent holds independently of the expected word order (Sauppe, 2016). These observations led to the conclusion that fixations are driven by the semantics of the verb rather than by the syntactic preferences for particular word orders (Sauppe, 2016). In the critical time region of our experiment, the comprehenders have already processed $\mathrm{NP}_{1}$ and are expected to perform anticipatory fixations to a further role filler of a transitive event. This time region is comparable with the time region after processing the first argument in a V-initial language, in which case fixations are oriented towards the not yet mentioned role filler (the agent in a VOS order or the patient in a VSO order). Hence, the predictions of the bias from the preferred word order and of a semantically-driven role anticipation are conflated in our design (see Sauppe, 2016 for a discussion of this conflation in V-medial orders in general).

4. I.4 Procedure. Participants were seated in a quiet room in front of a display and an eye-tracker camera. They were instructed to place headphones on for the experiment, and to observe the picture scene on the screen, to listen to the audio stimuli and to answer a follow-up question after each item. Visual stimuli were presented through the Experiment Builder (by SR Research EyeLink). Once the participants read the instructions, they pressed a key on the keyboard to start the experiment. At the beginning of each trial, a fixation cross in the middle of the screen was presented for two seconds. The visual stimulus appeared on the screen and the audio stimulus started $2000 \mathrm{~ms}$ later. Each experimental session started with three trial practice sentences, followed by the actual study. On average, an experimental session lasted 20 minutes.

4.I.5 Data analysis. Eye gazes were tracked by an EyeLink 1000 at $500 \mathrm{~Hz}$ sampling rate (viewing was binocular, but only the right eye was tracked). Fixations to three interest areas corresponding to the three characters were recorded with the EyeLink Data Viewer tool, starting from the time point of the appearance of the visual stimulus ( $2000 \mathrm{~ms}$ before the audio stimulus) and up to 500 $\mathrm{ms}$ after the offset of the audio stimulus. Starting and end time points of eye fixations on the interest areas were further processed in $\mathrm{R}$, version 4.0.2, for the creation of descriptive summaries, visualizations, and statistical analyses (R Core Team, 2020). Word regions of the verbal stimuli differ in duration; see 4.1.2. Therefore, the eye-tracking data were time-normalized in order to be comparable across trials (see Sauppe, 2016). Fixation data were grouped for time bins of $100 \mathrm{~ms}$ in the time-normalized data. ${ }^{6}$ For each bin we calculated the empirical logit with an adjustment factor $e=$ 0.5 (Agresti, 2002; Barr, 2008).

The recorded eye fixations form a polytomous variable: fixations on the agent and patient role fillers; fixations on the middle (ambiguous) character; fixations outside the characters. These data were converted into two dichotomous variables reflecting the nesting of these areas of eye fixation with respect to the questions at issue (Barr, 2008; Knoeferle et al., 2005). In a first step, we collapsed the fixations on agents and patients into a single group and calculated their relation to fixations in all interest areas (including the middle character). In the critical time region after $\mathrm{NP}_{1}$ and up to $\mathrm{NP}_{2}$, fixations on the peripheral characters are informative for the time course of the visual search for role fillers. In a second step, we calculated the relation between fixations on the agent and fixations on the patient, which is informative for the exact role filler (patient or agent) that is anticipated in the critical time region.

The fixation data were fitted by linear mixed-effects models, following the procedure recommended by Barr (2008) and Mirman (2014); run by the function lmer, package lme4, version 
1.1-23 in $R$ (Bates et al., 2015). The analysis was based on a quasi-logistic linear model with the empirical logit of fixations as dependent variable, calculated for time bins of normalized $100 \mathrm{~ms}$. Since each participant was exposed to each item once, the empirical logit can be only calculated for subjects and items separately (within a time bin), which requires two analyses (by subjects/by items) (Barr, 2008; Mirman, 2014). ${ }^{7}$ For the analysis of fixations on role fillers, the empirical logit was computed with the sum of fixations on the peripheral characters, divided by the sum of fixations to the middle character within the same time bin and logarithmized with an adjustment factor $e=0.5$ (Agresti, 2002), following the usual practice in the analysis of fixation data in the visual world paradigm (Arai et al., 2007; Carminati \& Knoeferle, 2013). The empirical logit for fixations on the agent was calculated with the sum of fixations on the agent over fixations on the patient within the same time bin.

The fixed effects of the linear model were the factors of interest (CASE and STRESS) and the continuous variable of TIME. The fixed factors CASE and STRESS were contrast-coded (sum contrasts): Stress: on the $\mathrm{V}=-1$, on $\mathrm{NP}_{1}=+1$; $\mathrm{CASE}_{1}$ of $\mathrm{NP}_{1}$ : Nom (Experiment 1) and Nom $\mid$ Acc (Experiment $2)=-1$, Acc $=+1$. With this contrast coding, the intercept is the mean of all means. The TIME variable was centralized and rescaled into seconds (in order to be in a numeric scale that is comparable with the further fixed effects). Analysis started with maximal models; the fixed effects were reduced by a backwards selection procedure based on AIC values (run by the function step, package stats, version 4.0.2 in $R$; R Core Team, 2020). Random effects were kept maximal in all analyses (Barr et al., 2013), containing intercepts for SubJects/Items and slopes of SubJects/Items (in the corresponding analysis) with the fixed factors of interest (CASE and STRESS), while Time could not be used in the random-effect structure, since it is a continuous variable. Weights were added to the linear regression, capturing the variation of the sums of valid datapoints across time bins: $w=1 /$ $(y+\varepsilon)+1 /(n-y+\varepsilon)$, whereby $w$ stands for weight, $y$ is the number of target events, $n$ the total number of events out of which $y$ is drawn, and $\varepsilon$ is the adjustment factor 0.5 (Barr, 2008; McCullagh \& Nelder, 1989; Mirman, 2014). ${ }^{8}$

The significance of the factors of interest was estimated with the LLTs comparing a model with the effect at issue and a model without this effect. These tests cannot be computed for effects nested in a significant interaction effect, since the components of an interaction cannot be dropped for model comparison. Whenever an effect is only significant in one of the random-factor analyses (by subjects or by items), we calculate a mint' value, based on the $t$-values of the individual analyses: $\left(t_{1} \times t_{2}\right) /\left(t_{1}+t_{2}\right)$ (see $m i n F^{\prime}$ in Raaijmakers et al., 1999).

\subsection{Results}

4.2.I Visual search for role fillers. The time course graph in Figure 4 shows the empirical logit of looks to the role fillers (see subsection 4.1.5). Fixations on role fillers decrease during $\mathrm{NP}_{1}$, since the speakers increasingly fixate the ambiguous character during its mention by $\mathrm{NP}_{1}$. In the critical time region between the onset of the $\mathrm{V}$ and the offset of the adverb, fixations on role fillers increase, which is the expected effect of anticipatory behavior. The final increase of the looks to the role fillers after the onset of $\mathrm{NP}_{2}$ is not part of the anticipatory behavior, since the one or the other role filler is mentioned by $\mathrm{NP}_{2}$ (Knoeferle et al., 2005). Crucially, the results reveal an effect of CASE in the critical region: fixations on role fillers reach a higher amount with accusative-first clauses.

In the verb region, the linear mixed-effects model with the maximal fit contains a significant effect of TIME (by subjects, $\beta_{1}=0.612$; LLT: $\chi^{2}=138.2, p<0.001$; by items, $\beta_{2}=0.615$; LLT: $\chi^{2}=135.9, p<0.001$ ), and a significant effect of CASE (by subjects, $\beta_{1}=0.185$; LLT: $\chi^{2}=10.4$, $p<0.01$; by items, $\beta_{2}=0.194$; LLT: $\chi^{2}=13.7, p<0.001$ ); see listing in Appendix C, Table 5/V, and plotted coefficients in the miniature graph of Figure 4 . The TIME $\times$ CASE interaction is only 


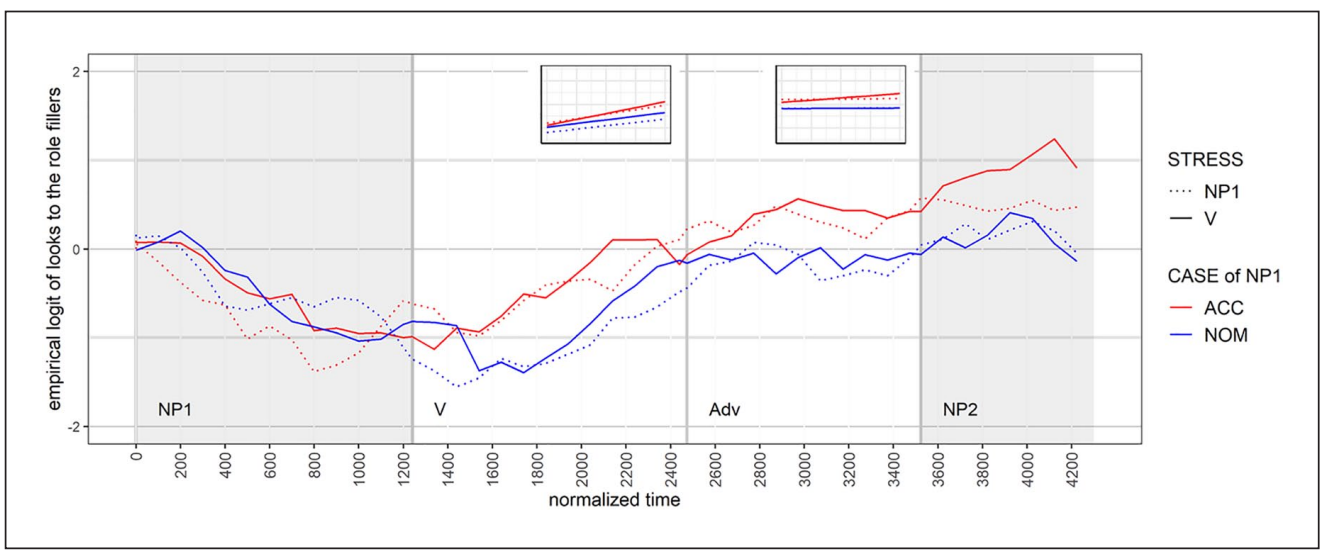

Figure 4. Case unambiguous clauses: fixations on role fillers (non-shaded area: critical time region for anticipatory fixations; miniature graphs: coefficients of the linear model).

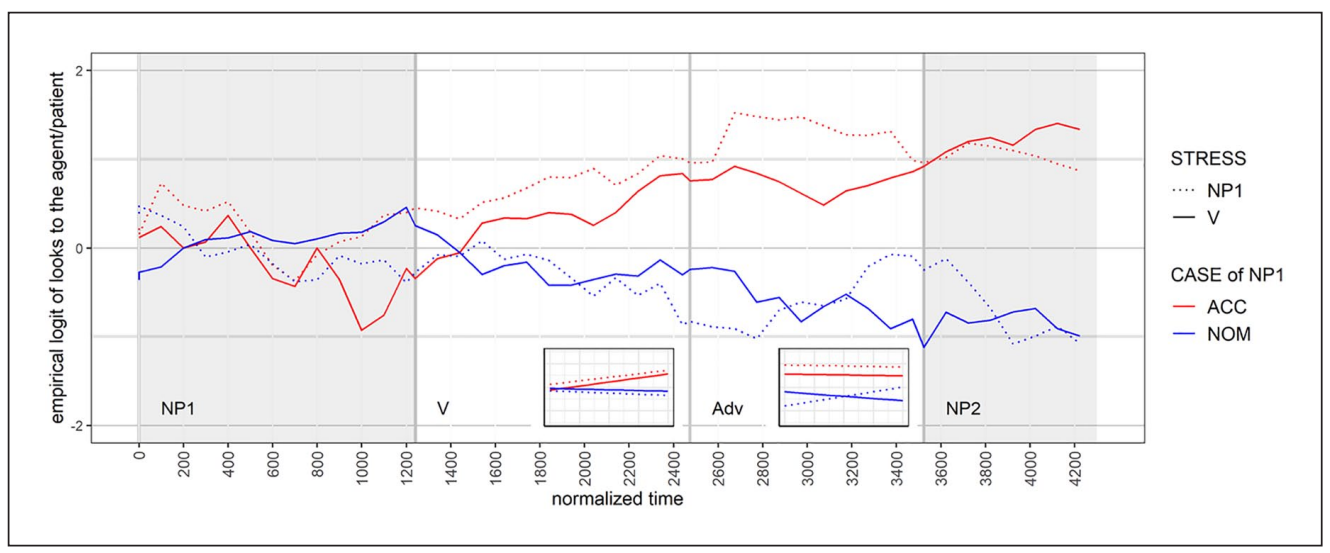

Figure 5. Case unambiguous clauses: fixations on the agent (vs. patient) (non-shaded area: critical time region for anticipatory fixations; miniature graphs: coefficients of the linear model).

significant in the analysis by subjects and is below significance in the mint ${ }^{\prime}$ test $\left(\right.$ mint $^{\prime}=0.94$; see details in subsection 4.1.5). In the adverb region, we only obtain a significant effect of CASE, $\beta_{1}=0.1$, LLT: $\chi^{2}=5.2, p<0.05 ; \beta_{2}=0.095$, LLT: $\chi^{2}=5.3, p<0.05$. The effect of TIME in the verb region is due to the increase of fixations on role fillers during time. The effect of CASE in both regions is due to the significantly higher proportion of fixations on role fillers with accusative than with nominative initial NPs.

4.2.2 Role anticipation. The time course graph in Figure 5 shows the empirical logit of looks to the agent over patient (since the verbs of this experiment are active, the agent is always the subject). The increase of looks to the patient after an initial nominative and the increase of looks to the agent after an initial accusative is evidence for anticipatory fixations. Since the case suffix is the final segment of $\mathrm{NP}_{1}$ (which is $300 \mathrm{~ms}$ before the verb onset), effects of case are expected to appear not earlier than by the verb onset. Interestingly, an initial stress has an impact on the gaze behavior 
depending on case, enhancing looks to the agent in the accusative-first order and looks to the patient in the nominative-first order during the early adverb region.

The linear mixed-effects models on the empirical logit of agent fixations reveal an interaction of TIME and CASE in the verb region, $\beta_{1}=0.332$, LLT: $\chi^{2}=24.8, p<0.001 ; \beta_{2}=0.346$, LLT: $\chi^{2}$ $=29.9, p<0.001$, nesting an effect of TIME, $\beta_{1}=0.203 ; \beta_{2}=0.141$, and an effect of CASE, $\beta_{1}=$ $0.222 ; \beta_{2}=0.28$; see Appendix C, Table 6/V. Since the intercept is not significant (see Appendix $\mathrm{C}$, Table 6), there is no evidence for an overall bias towards an SVO order, as it would be expected by the corpus facts in Section 2. In the adverb region, we obtain a threefold interaction effect, $\beta_{1}=-0.294$, LLT: $\chi^{2}=17.8, p<0.001 ; \beta_{2}=-0.281$, LLT: $\chi^{2}=15.8, p<0.001$, nesting an interaction between Time and STRESS, $\beta_{1}=0.289 ; \beta_{2}=0.292$, and an effect of CASE, $\beta_{1}=0.551 ; \beta_{2}=0.587$; see Appendix C, Table 6/Adverb. The sources of this interaction are visible in Figure 5: initial stress enhances looks to the agent in the accusative-first order and looks to the patient in the nominative-first order during the early adverb region, while stressed nominative-first orders show an increase of the looks to the agent towards the late adverb region.

\subsection{Discussion}

The results of the visual search for role fillers (see Figure 4 in subsection 4.2.1) reveal an asymmetry between nominative and accusative case, which is also reported for eye tracking data in other languages (see Finnish in Kaiser \& Trueswell, 2004); see predictions in subsection 4.1.3. This asymmetry is accounted for by the fact that accusative is a non-default case as well as by the fact that processing an accusative case invokes the expectation of a nominative, while an initial nominative may be part of a minimal complete clause without a further argument (see minimality account in Bornkessel-Schlesewsky \& Schlesewsky, 2009). However, the main effect of CASE is retained after processing the transitive verb (in the adverb region), that is, the visual search for role fillers is still stronger with accusatives than with nominatives in the time area in which a further argument is expected with either case. This effect can only be explained as an effect of markedness: the non-default case (initial accusative) has a stronger effect on the anticipatory behavior than the default case (initial nominative).

The findings from role anticipation (see subsection 4.2.2) contain interaction effects between TIME and the fixed effects in the verb region. These interactions are "rate effects," reflecting a change of the eye gaze behavior during time (Barr, 2008; Mack et al., 2013). The difference between cases starts shortly after the onset of the verb region. The effect of CASE increases with the course of time (see Figure 5), which is evidence for an influence of the immediately preceding processing events (i.e., $\mathrm{NP}_{1}$ ).

Our results do not display a significant intercept in the verb region (see Appendix C, Table 6), that is, fixations are driven by CASE without an overall preference for interpreting the first argument as a subject due to the preferred word order - as stated in (4b) - or as an agent (due to the prominence of agents in event comprehension; see subsection 4.1.3). Previous studies reported that the bias towards an SVO word order is weak in the presence of case cues in Hungarian (MacWhinney et al., 1985). This finding differs from languages such as German in which a SVO bias is already observed with unambiguous initial accusatives during comprehension (Kamide et al., 2003); see further discussion in Section 6.

The comparison between the effects of CASE on visual search and on role anticipation reveals that an initial accusative has a different impact on visual search for role fillers than the default nominative (see subsection 4.2.1); however, to the extent that comprehenders seek for a role filler, the effect of accusative in triggering fixations towards the agent does not differ in magnitude from the effect of nominative in triggering fixations towards a patient (since the intercept in the verb region is not significant). 
STRESS does not have a significant effect in the verb region, such that the effects of STRESS show up later than the effects of CASE. This difference may well result from the fact that prosodic prominence is a relational concept: the nuclear stress on either the $\mathrm{NP}_{1}$ or the $\mathrm{V}$ can only be computed after processing the intonational properties of both constituents. Late timing of accentual prominence is also reported by Weber et al. (2006b) on German: effects of STRESS are found in the adverb region and not during the verb. In the early adverb region, STRESS enhances anticipatory behavior in whatever direction is supported by case cues. This is a well-known function of accentual prominence, reported in several eye-tracking studies (Sedivy et al., 1999; Weber et al., 2006a).

Finally, fixations to the agent increase with stressed nominatives in the late adverb region rendering a cross-over effect with unstressed nominatives. This effect does not follow from the predictions presented so far. We speculate that fixations to the agent reach a ceiling effect early in the adverb region, followed by fixations to the alternative character up to the onset of $\mathrm{NP}_{2}$, which refers to the patient character. Note that the fixations to the agents in the adverb region are slightly decreasing with stressed accusative $\mathrm{NP}_{1}$, which is the mirror image of the effect of the nominatives.

\section{Experiment 2: case ambiguity and stress}

Experiment 1 established a baseline for the role of case and prosody. The aim of Experiment 2 is to examine the role of prosody on the incremental thematic role assignment with locally ambiguous sentences. The visual material, the procedure, and the method of data analysis used in Experiment 2 were identical to Experiment 1; see subsections 4.1.2, 4.1.4, and 4.1.5, respectively.

\section{I Method}

5.I.I Participants. Twenty-four native speakers (16 females, eight males; age range: 19-28; age average: 22.04; all right-handed; either uncorrected vision or corrected to normal, no sight impairments; speakers with prior knowledge of psycholinguistics research methods were excluded). None of the participants of this experiment had participated in Experiment 1. Recordings took place at the University of Debrecen, Hungary. Participants freely offered informed consent (written) and were paid 3000 Hungarian Forint for their participation.

5.I.2 Material. The factorial design contained the factors CASE and STRESS; see Table 4. In Experiment 2, initial accusatives were compared with ambiguous (nominative/accusative) initial NPs. The local ambiguity was resolved by the last NP that was unambiguously nominative (XVS order).

The OVS utterances in Experiment 2 were the same as in Experiment 1; see (8b). Nominative/ accusative ambiguity in the XVS level was implemented through possessed nominals of the 1 st person singular, as in (9) (see listing of the items in Appendix A/XVS); compare (8), see also discussion in Section 2, (1c). ${ }^{9}$

(9)
$\mathrm{NP} 1_{\mathrm{NOM} \mid \mathrm{ACC}} \cdots$
A béká-m néz-i mindjárt a lepke.
DEF frog-Poss.1sG [NOM|ACC] watch-3sg soon DEF butterfly [NOM]
"The butterfly watches soon my frog."

The OVS recordings of Experiment 1 were also used in Experiment 2 (see subsection 4.1.2); the XVS utterances were performed with the same intonational pattern. Figure 6(a) illustrates an XVS utterance with initial stress. The high target of the intonational nucleus is aligned with the stressed syllable of the initial noun; compare SVO in Figure 2. The median excursions of the XVS stimuli 
Table 4. Factorial design of experiment 2 (the constituents bearing the nuclear stress are underlined).

\begin{tabular}{|c|c|c|}
\hline \multicolumn{2}{|l|}{ Factors } & \multirow[t]{2}{*}{ Conditions } \\
\hline CASE & StRESS & \\
\hline \multirow{2}{*}{$\mathrm{NP}_{\mathrm{NOM} \mid \mathrm{ACC}} \cdots$} & $N P \vee N P$ & X-Verb-Subject \\
\hline & $\overline{N P} \vee N P$ & $\bar{X}$-Verb-Subject \\
\hline \multirow[t]{2}{*}{$\mathrm{NP}_{\mathrm{ACC}} \cdots$} & $\mathrm{NP} \overline{\mathrm{V}} \mathrm{NP}$ & Object-Verb-Subject \\
\hline & $\overline{\mathrm{NP}} \vee N P$ & $\overline{\text { Object-Verb-Subject }}$ \\
\hline
\end{tabular}

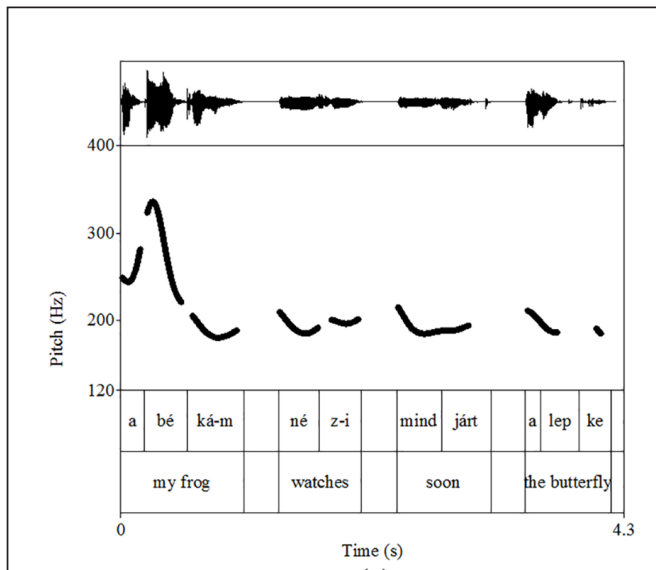

(a)

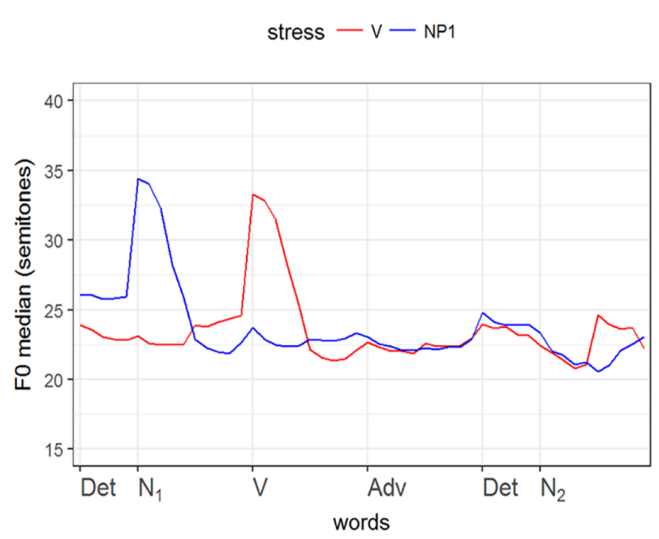

(b)

Figure 6. Fundamental frequency (F0)-excursions of XVS utterances; see morphemic transcription in (9): (a) illustrative XVS example; (b) FO median excursions.

in Figure 6(b) are very similar to the median excursions for SVO/OVS utterances in Figure 3 (see procedure for the extraction of the measurements in subsection 4.1.2). All further properties of the material (visual stimuli, fillers, and distribution in lists) were identical with Experiment 1 (subsection 4.1.2). Altogether, we evaluated $(24$ speakers $\times 24$ items $=) 576$ trials.

5.I.3. Predictions. The OVS conditions are expected to replicate the pattern in Experiment 1, so we expect to find anticipatory looks to the agent after processing $\mathrm{NP}_{1}$. A case-ambiguous $\mathrm{NP}_{1}$ (XVS) is expected to be interpreted by default as a subject, since the SVO order is 3.2 times as likely as OVS in Hungarian (Table 1). The corpus frequencies in Section 3 (Table 2) predict that the subject-first bias will be weaker with foci than with topics. We did not find such a bias with case-unambiguous NPs in Experiment 1, but if prosodic cues are activated to resolve ambiguity, we expect to find effects of stress with case ambiguous NPs.

\subsection{Results}

5.2.I. Visual search for role fillers. Figure 7 presents the time course of fixations on role fillers in Experiment 2. The effect of CASE is similar to the effect observed in Experiment 1. With the accusative-first order, anticipatory looks to role fillers start earlier and are more numerous. Case ambiguous initial NPs show a pattern that is similar to the nominative-first sentences in Experiment 1. 


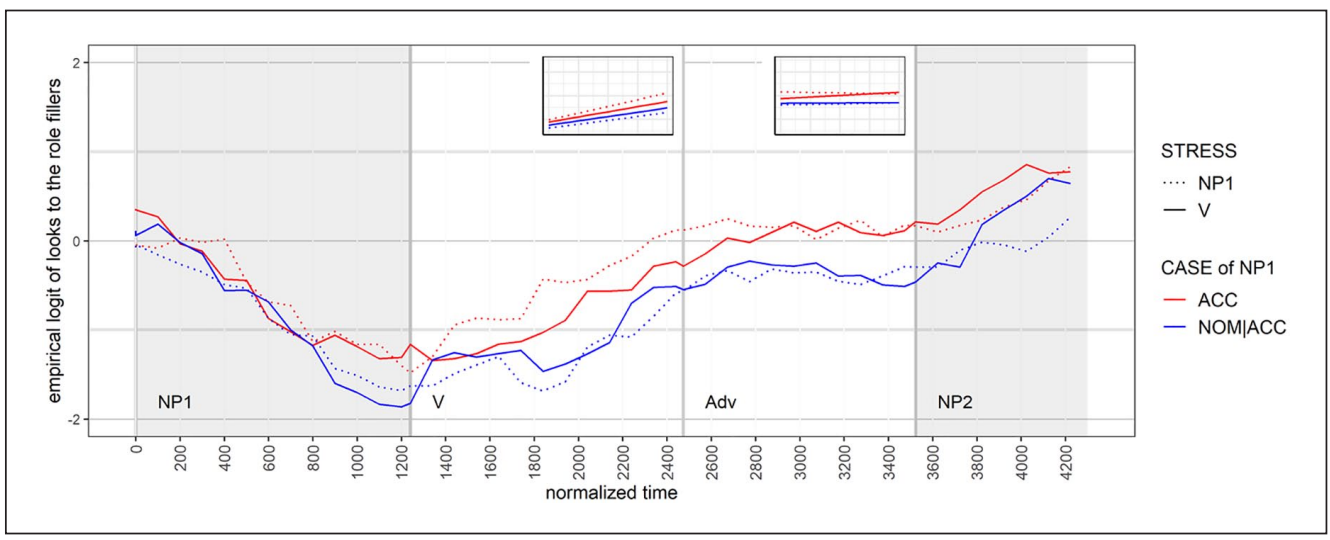

Figure 7. Case ambiguity of the initial NP: fixations on role fillers (non-shaded area: critical time region for anticipatory fixations; miniature graphs: coefficients of the linear model).

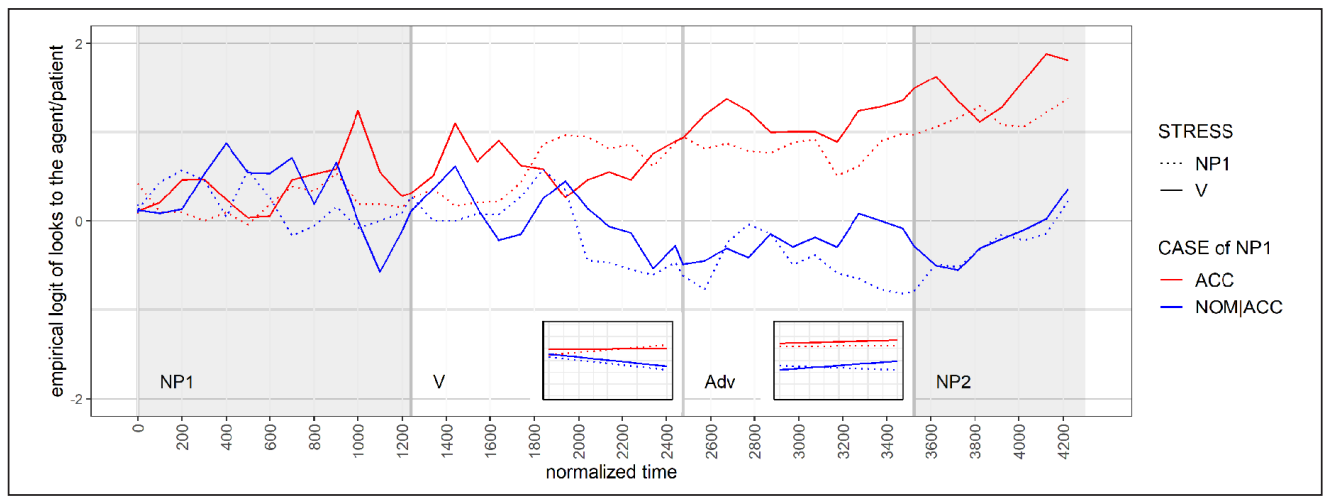

Figure 8. Case ambiguity of the initial NP: fixations on the agent (vs. patient) (non-shaded area: critical time region for anticipatory fixations; miniature graphs: coefficients of the linear model).

Within the verb region, the linear mixed-effects models of maximal fit (by subjects and items) contain a significant interaction between TIME and CASE, $\beta_{1}=0.13$, LLT: $\chi^{2}=6.8, p<0.01 ; \beta_{2}=$ 0.134, LLT: $\chi^{2}=7.9, p<0.01$, nesting an effect of CASE, $\beta_{1}=0.197 ; \beta_{2}=0.179$, and an effect of Time, $\beta_{1}=0.707 ; \beta_{2}=0.71$; see Appendix $\mathrm{C}$, Table $7 / \mathrm{V}$. The threefold interaction effect $\left(\right.$ mint $\left.{ }^{\prime}=2.1\right)$ and the CASE $\times$ STRESS interaction $\left(\right.$ mint ${ }^{\prime}=1.35$ ) is not significant across random factors. In the adverb region, we only obtain a significant effect of CASE, $\beta_{1}=0.201$, LLT: $\chi^{2}=15.9, p<0.001$; $\beta_{2}=0.045$, LLT: $\chi^{2}=14.2, p<0.001$, which is due to the higher number of fixations on role fillers with accusative-first clauses.

5.2.2 Role anticipation. Figure 8 shows the time course of fixations on the agent versus patient. Accusative-initial sentences show a clear incline towards the agent. The fixations curve of ambiguous-initial sentences shows a fall of the looks to the agent starting around the middle of the verb region (at $1900 \mathrm{~ms}$ ). The difference between accusative-first and ambiguous-first utterances starts later than in Experiment 1 (roughly $700 \mathrm{~ms}$ after the onset of the V). Furthermore, the gaze behavior 
with ambiguous-first sentences is very close to the 0 level of the log odds (equally frequent fixations on both role fillers) with a slight preference towards the patient starting later in the verb region (around $2200 \mathrm{~ms}$ from the sentence onset). Until the end of the adverb region, looks to the patient are more frequent, which suggests that the comprehenders assume an initial nominative NP. This assumption is revised in $\mathrm{NP}_{2}$, which triggers an increase of the fixations on the mentioned role filler (agent), starting around $300 \mathrm{~ms}$ after the onset of $\mathrm{NP}_{2}$.

The gaze behavior in the verb region results in a significant interaction effect between TIME and CASE, $\beta_{1}=0.321$, LLT: $\chi^{2}=22.8, p<0.001 ; \beta_{2}=0.346$, LLT: $\chi^{2}=27.9, p<0.001$, and nesting an effect of CASE, $\beta_{1}=0.268 ; \beta_{2}=0.203$; see Appendix C, Table $8 / \mathrm{V}$. The threefold interaction is only significant in the analysis by items and not in the combined analysis of both random factors $\left(\right.$ mint $\left.^{\prime}=1.25\right)$. In the adverb region, the model of maximal fit involves a negative interaction effect of Time and STRESs, $\beta_{1}=-0.16$, LLT: $\chi^{2}=5.1, p<0.05 ; \beta_{2}=-0.274$, LLT: $\chi^{2}=12.7, p<0.001$, and a significant effect of CASE, $\beta_{1}=0.477$, LLT: $\chi^{2}=23.7, p<0.001 ; \beta_{2}=0.463$, LLT: $\chi^{2}=$ 23.9, $p<0.001$; see Appendix C, Table 8/Adverb. The threefold interaction is not significant in the mint' test $\left(\right.$ mint $\left.^{\prime}=1.5\right)$.

\subsection{Discussion}

The visual search for role fillers in the verb region shares in common with Experiment 1 that the non-default case has a stronger effect on anticipatory behavior than the zero-marked $\mathrm{NP}_{1}$ (which is a nominative in subsection 4.2.1 and case-ambiguous with possessive constructions in subsection 5.2.1). This is reflected in the main effect of CASE in the verb and adverb region (see discussion in subsection 4.3). The results of Experiment 2 differ from Experiment 1 in involving an interaction effect between TIME and CASE. This is a rate effect only appearing in the comparison between caseunambiguous and case-ambiguous NPs: fixations on role fillers increase more rapidly with accusative-first clauses, compared to ambiguous-first clauses.

The findings from role anticipation (subsection 5.2.2) reveal an interaction between TIME and CASE in the verb region, resulting from the increase of the difference between accusative-first and ambiguous-first clauses over time (similar to Experiment 1; see subsection 4.2.2). The effect of CASE reveals that the case-ambiguous $\mathrm{NP}_{1}$ is interpreted as a subject/agent, which triggers anticipatory fixations to the patient character in the verb region. This effect is similar to the effect of nominative $\mathrm{NP}_{1}$ in Experiment 1, but the cue for thematic role assignment does not come from case marking. The interpretation of an initial subject/agent follows from the bias from the preferred word order in (4b) and is in line with previous findings that comprehenders assume an SVO order in the absence of unambiguous morphological cues in Hungarian (MacWhinney et al., 1985; Pléh, 1981).

Anticipatory effects start later with case-ambiguous NPs: the averaged fixations show a tendency towards the patient (below the 0 level) in the late verb region (compare with subsection 4.2.2), which may reflect the uncertainty in processing $\mathrm{NP}_{1}$ in the absence of a case cue. Studies on other languages show that case ambiguity is not a sufficient condition for a delay in anticipatory fixations. For instance, Knoeferle et al. (2005) and Zhang \& Knoeferle (2012) report that caseambiguous initial NPs in German are associated with an increase of anticipatory fixations on the patient (revealing a subject interpretation of $\mathrm{NP}_{1}$ ) starting early within the verb region. Hence, the delay of the anticipatory fixations in Hungarian XVS clauses (compared to the early reaction obtained in Experiment 1) cannot be explained by ambiguity alone. However, German has been shown to have a strong SVO bias in comprehension that is even attested with initial accusatives, which is not the case for Hungarian; see discussion in subsection 4.3. The present difference is a further instance of the same phenomenon: the bias of the preferred word order has a stronger effect 
in resolving case ambiguities in German than in Hungarian. The typological difference that may be the source of this difference is discussed in Section 6.

In the adverb region, the significant effect of CASE confirms the difference between accusativefirst versus ambiguous-first sentences on agent fixations. The negative interaction of STRESS and TIME is due to the increase of fixations to the patient in sentences with initial stress (during the adverb region). This finding is different from the effects reported for German in Weber et al. (2006b): with case-ambiguous initially-stressed utterances, anticipatory fixations on the agent increase in the adverb region, indicating that initial stress triggers an accusative-first reading. Certainly, Hungarian shows a different pattern (increase of fixations to the patient), which is reminiscent of the focus-to-subject association reported by MacWhinney et al. (1985). This result is not in line with the "focus-to-object" inference predicted by (7). It may be an effect of prosodic prominence in strengthening the disambiguation of the initial NP as a subject (similar to the effects observed in the early adverb region of Experiment 1). However, this can only be a weak conclusion out of our data: crucially, we did not find a significant interaction between CASE and STRESS, which would indicate that the increase of fixations to the patient exactly applies to initially ambiguous sentences.

\section{General discussion and conclusions}

The presented experiments offer evidence for the relative strength of case, stress, and word order as cues for thematic role assignment in Hungarian. In an agglutinative language with highly reliable and almost always available case suffixes, case is the most reliable cue when it comes to thematic role assignment (Bates et al., 1982), as has been already shown for Hungarian (MacWhinney et al., 1985). Our studies confirm these findings in on-line comprehension. Processing a clauseinitial nominative increases the anticipatory fixations on the patient and a clause-initial accusative leads to more fixations on the agent, while the rate effect (TIME and CASE interaction) confirms that this difference is due to the influence of the preceding word region (Experiment 1).

Furthermore, our data reveal a difference between cases, reflecting their markedness asymmetry. In both experiments, the visual search for role fillers increases earlier with marked case (accusative) than with bare nominals (nominative in Experiment 1 or ambiguous in Experiment 2), resulting in a significant effect of CASE within the verb region. In both experiments, the difference between cases on the visual search for role fillers remains after processing the transitive verb (Figure 4 and Figure 7). This finding shows a stronger impact of the marked case (accusative) on anticipatory behavior, that is relevant also after excluding the possibility of an intransitive structure (Longenbaugh \& Polinsky, 2016):

(10) Marked case has a stronger impact on visual search than unmarked case.

The preferred word order in Hungarian predicts a bias for initial subjects in speech comprehension; see (4b). In the absence of case marking (Experiment 2), this bias explains the anticipation of a patient after processing a case-ambiguous $\mathrm{NP}_{1}$. In the presence of case marking, processing a nominative $\mathrm{NP}_{1}$ increases fixations to the patient and processing an accusative $\mathrm{NP}_{1}$ increases fixations to the agent - there is no evidence for a bias from the preferred word order or from the prominence of agents in event comprehension modulating the effect of case (no significant intercept in the verb region; see subsection 4.3). This finding is in line with previous observations that the bias for subjectinitial clauses only applies in the absence of stronger morphosyntactic cues in Hungarian and is evidence for a strong impact of case cues in this language (MacWhinney et al., 1985; Pléh, 1981). 
(11) A bias for initial subjects applies in the absence of case cues in Hungarian.

This finding is subject to cross-linguistic variation. In German, a subject-first bias is also observed with accusative-marked initial NPs (Kamide et al., 2003). Similar results are reported for agglutinative languages that display more instances of case ambiguity than Hungarian (see Erdocia et al., 2009 on Basque by means of errors in comprehension tasks). Hence, the strength of the case cues is not explained by the reliability of the case cues in agglutinative languages, since the absence of allomorphy of the accusative marker equally applies to Basque and Hungarian. However, Hungarian differs from German and Basque regarding the availability of case cues: while case ambiguity appears with various constructions in Basque and with most inflectional paradigms in German (all inflectional paradigms except for masculine singular), case ambiguity is very limited in Hungarian; see (4a). Hence, we hypothesize that the difference in the availability of case (across constructions) is the crucial source of cross-linguistic variation that accounts for the difference between these languages.

STRESS had a role in the anticipation of role fillers in both experiments. In Experiment 1, stress on $\mathrm{NP}_{1}$ induces an increase of the fixations on the agent with initial accusatives and an increase of the fixations on the patient with initial nominatives in the early adverb region (subsection 4.2.2). These findings confirm the view that stress "increases the saliency of case markers" (Pléh, 1981, p. 340). The increase of fixations on the patient with case-ambiguous NPs (Experiment 2) extends this view beyond case markers. Focus (expressed by prosodic prominence) attracts attention (Sedivy et al., 1999; Weber et al., 2006a), enhancing the effects of case (with nominative-initial or accusative-initial clauses) or the effects of word order (i.e., the subject-first bias with case-ambiguous initial clauses).

(12) Prosodic prominence attracts attention and enhances the effects of the available morphosyntactic cues.

The effect of STRESS on thematic role assignment is mediated by information structure - initial foci are less frequently subjects of this than initial topics; see (7). If comprehension was driven by the accumulation of likelihoods in discourse, as suggested by cue-competition accounts (Chan, Lieven and Tomasello, 2009), we would expect to obtain a main effect of STRESS with case-unambiguous clauses, such that initial stress enhances the expectation of an OVS order and induces fixations on the agent after processing the $\mathrm{NP}_{1}$. This prediction is not corroborated by the results of Experiment 1 (i.e., in the presence of unambiguous case marking), in line with previous research on the role of prosody in the resolution of ambiguities (Allbritton et al., 1996; Snedeker \& Trueswell, 2003). This is an important finding indicating that comprehension is not straightforwardly mapped onto discourse frequencies. Probabilistic cues such as prosody play a role only in the absence of non-probabilistic cues such as case.

(13) Prosodic cues do not contribute to thematic role assignment in the presence of unambiguous cues such as case.

The appropriate conditions for the activation of prosodic cues are fulfilled by case-ambiguous clauses in Experiment 2. In other languages, initial stress has been shown to reduce the subject-first bias in sentence comprehension (see Weber et al, 2006b and Grünloh et al., 2011 on German; MacWhinney et al., 1984 on German and Italian). In Hungarian, previous studies report the opposite effect: initial stress enhances the subject-first bias (tested with non-grammatical instances of 
ambiguity by MacWhinney et al., 1985). Our results suggest that this type of effect can be understood as a general effect of prosodic prominence as postulated in (12).

The difference between Hungarian and Italian/German leads to a typology between languages that draws inferences from prosody and languages using prosody for the enhancement of morphosyntactic cues. Can this typology be predicted by independent cross-linguistic differences? A relevant difference between Hungarian and Italian/German lies in the availability of case contrasts across paradigms. Nominative-accusative ambiguity appears with most inflectional paradigms in German (all paradigms expect masculine singular) and all inflectional paradigms of Italian. In Hungarian, ambiguity only arises in particular constructions with possessed NPs, in which the accusative suffix can be dropped. Moreover, the case-ambiguous form (dropped accusative) is string identical to a zero-marked nominative. In conjunction with the word order preferences when presented clause initially, this form results into a strong bias to interpret the initial NP as a nominative. The morphosyntactic properties of Hungarian, in particular the high reliability and the high availability of case marking, is a crucial difference to German/Italian that may account for the findings of several studies that prosodic cues modulate the subject-first bias only in the latter languages.

Our experiments belong to a paradigm of studies that examine the impact of morphosyntactic and prosodic cues of thematic role disambiguation without using context. The reasoning of these experimental manipulations is to pin down the effects and interactions between cues at the clausal level. In interpreting prosodic cues, the role of information structure is crucial for languages such as German, Italian or Hungarian. Since prosody does not encode syntactic functions in this language type but is used to differentiate topics and foci, considering information structure is crucial for understanding the role of prosodic cues. However, a limitation is due: the results obtained by these experiments are informative for the different cues at the clause level, but cannot be generalized for the impact of information structure established through contextual cues. We know from studies comparing contextual cues (e.g., Grünloh et al., 2011) that the effect of information structure is enhanced if contextual cues are present. The studies examining thematic role assignment without context show that the competition of cues at the clausal level differs between languages - the challenge is to understand this variation in terms of the differences of the grammars at issue.

\section{Acknowledgements}

The experimental design was developed in collaboration with Pia Knoeferle (Humboldt University of Berlin). The stimuli used in the experimental studies are part of the PhD thesis of Julia Kröger (Bielefeld University). We are grateful to Kriszta Szendröi and Jenneke van der Wal for their comments on an earlier version of this manuscript.

\section{Funding}

The authors disclosed receipt of the following financial support for the research, authorship, and/or publication of this article: This article is part of the project "Focus and thematic role assignment: A comparison of Hungarian and German in Child Language Comprehension" (Bielefeld University, Humboldt University of Berlin, Georg-August-University Göttingen, funded by the German Research Foundation, within the priority program XPRAG.de, "New Pragmatic Theories based on Experimental Evidence" (SPP 1727); principal investigators: Pia Knoeferle and Stavros Skopeteas).

\section{ORCID iD}

Stavros Skopeteas (iD https://orcid.org/0000-0002-2827-0518 


\section{Notes}

1. The notation in the examples follows standard practices in grammatical research: $a\left({ }^{*} b\right)$ stands for " $a$ is well-formed but $a b$ is not so," $a^{*}(b)$ stands for " $a b$ is well-formed but $a$ is not so." Abbreviations for glosses: $1=1$ st person; $3=3$ rd person; $\mathrm{ACC}=$ accusative; $\mathrm{CMPR}=$ comparative; $\mathrm{DEF}=$ definite; $\mathrm{INDEF}=$ indefinite $; \mathrm{NOM}=$ nominative $; \mathrm{PFV}=$ perfective $; \mathrm{PL}=$ plural $; \mathrm{POSS}=$ possessive $; \mathrm{PST}=$ past $; \mathrm{SG}$ $=$ singular.

2. A very much discussed issue in Hungarian syntax is the exhaustive interpretation of the focus position (É Kiss, 1998; Szabolcsi, 1981). The interpretative properties of this position have been the issue of several experimental studies around the question whether exhaustivity is an intrinsic property of focus fronting in Hungarian or rather the product of pragmatic inferences (Káldi \& Babarczy, 2018; Onea \& Beaver, 2011).

3. $(\ldots) \mathrm{l}=$ left/right boundaries of intonational phrase; $*=$ nuclear stress.

4. Verbal particles are used for the formation of (compound) verbs. Most particles originate in directional elements but their exact contribution to the verb formation is idiomaticized. They have an impact on the lexical aspect of the compound verb by creating telic and resultative verbs (Kiefer, 2006; Rounds, 2001). The frequency scale correlates with the degree of desemanticization of the particles: the most frequent ones (in particular the particles meg and $e l$ ) are reduced to aspectual markers and do not have a substantial contribution to the lexical meaning (Rounds, 2001).

5. Model 1: glmer (synfunction $\sim$ dfunction $+(1+$ dfunction|verb), family $=$ "binomial"); Model 2: glmer (synfunction $\sim(1+$ dfunction $\mid$ verb $)$, family = "binomial").

6. Time normalization was conducted with dividing the duration of each word region (see Figures 4-5 and 7-8: from the onset of every word to the onset of the next word or-for the last word - from the onset to the offset) in intervals of duration $\Delta_{\text {bin }} \times \Delta_{\text {region }} / \Delta_{\text {mean }}$, whereby $\Delta_{\text {region }}$ is the duration of the word region in the stimulus at issue, $\Delta_{\text {mean }}$ is the average duration of the respective word region (in all stimuli) and $\Delta_{\text {bin }}$ is the duration of the time bin used for the analysis (100 milliseconds). Hence, the number of time bins per region is kept constant across stimuli (and has an average duration of 100 milliseconds in all regions).

7. A generalized linear mixed-effects model would allow for a single analysis with participants and items as random effects. However, these models do not converge for the majority of the analyses that we run in this study, which can only be resolved with reducing the random-effect structure.

8. R-formula: $\operatorname{lmer}($ elog $\sim$ Time $*$ Case $*$ Stress $+(1+$ Case $*$ Stress $\mid$ Random $)$, data $=$ dataset, weights $=1$ /weights, REML $=\mathrm{F}$ ), whereby "elog" is the empirical logit of fixations on role fillers or of fixations on the agents; "Random" stands for Subject in the analysis by subjects, and Item in the analysis by items; weights were corresponding to the $\mathrm{n}$ of valid tokens, see formula in subsection 4.1.5.

9. We selected 1st person possessives only, because in comprehension tasks with audio stimuli, the 2 nd person possessive suffix $(-d)$ can be easily misinterpreted as accusative suffix $(-t)$.

\section{References}

Agresti, A. (2002). Categorical data analysis. John Wiley \& Sons.

Arai, M., van Gompel, R. P. G., \& Scheepers, Chr. (2007). Priming ditransitive structures in comprehension. Cognitive Psychology 54(3), 218-250. https://doi.org/10.1016/j.cogpsych.2006.07.001

Allbritton, D. W., McKoon, G., \& Ratcliff, R. (1996). Reliability of prosodic cues for resolving syntactic ambiguity. Journal of Experimental Psychology: Learning, Memory, and Cognition, 22(3), 714-735. https://doi.org/10.1037//0278-7393.22.3.714

Allopenna, P. D., Magnuson, J. S., \& Tanenhaus, M. K. (1998). Tracking the time course of spoken word recognition using eye movements: Evidence for continuous mapping models. Journal of Memory and Language, 38(4), 419-439. https://doi.org/10.1006/jmla.1997.2558

Altmann, G. (2011). Language can mediate eye movement control within 100 milliseconds, regardless of whether there is anything to move the eyes to. Acta Psychologica, 137(2), 190-200. https://doi. org/10.1016/j.actpsy.2010.09.009

Barr, D. J. (2008). Analyzing "visual world" eyetracking data using multilevel logistic regression. Journal of Memory and Language, 59(4), 457-474. https://doi.org/10.1016/j.jml.2007.09.002 
Barr, D. J., Levy, R., Scheepers, C., \& Tily, H. J. (2013). Random effects structure for confirmatory hypothesis testing: Keep it maximal. Journal of Memory and Language, 68(3), 255-278. https://doi.org/10.1016/j. jml.2012.11.001

Bates, D., Mächler, M., Bolker, B., \& Walker, S. (2015). Fitting Linear Mixed-Effects Models Using lme4. Journal of Statistical Software, 67(1), 1-48. https://doi.org/10.18637/jss.v067.i01

Bates, E., McNew, S., MacWhinney, B., Devescovi, A., \& Smith, S. (1982). Functional constraints on sentence processing: A cross-linguistic study. Cognition, 11(3), 245-299. https://doi.org/10.1016/00100277(82) $90017-8$

Boersma, P., \& Weenink, D. (2019). Praat: Doing phonetics by computer [Computer program]. Version 6.0.50, retrieved 31 March 2019 from http://www.praat.org/

Bornkessel-Schlesewsky, I., \& Schlesewsky, M. (2009). Minimality as vacuous distinctness: Evidence from cross-linguistic sentence comprehension. Lingua, 119(10), 1541-1559. https://doi.org/10.1016/j.lingua.2008.03.005

Carlson, K. (2009). How prosody influences sentence comprehension. Language and Linguistics Compass, 3(5), 1188-1200. https://doi.org/10.1111/j.1749-818x.2009.00150.x

Carminati, M. N., \& Knoeferle, P. (2013). Effects of speaker emotional facial expression and listener age on incremental sentence processing. PLoS One 8(9), 1-16. https://doi.org/10.1371/journal.pone.0072559

Chafe, W. L. (1976). Givenness, contrastiveness, definiteness, subjects, topics, and point of view. In C. N. Li (Ed.), Subject and topic (pp. 25-55). Academic Press.

Chan, A., Lieven, E., \& Tomasello, M. (2009). Children's understanding of the agent-patient relations in the transitive construction: Cross-linguistic comparisons between Cantonese, German and English. Cognitive Linguistics, 20(2), 267-300. https://doi.org/10.1515/COGL.2009.015

Clark, H., \& Haviland, S. (1977). Comprehension and the given-new contrast. In R. O. Freedle (Ed.), Discourse production and comprehension (pp. 1-40). Lawrence Erlbaum Associates.

Cohn, N., \& Paczynski, M. (2013). Prediction, events, and the advantage of Agents: The processing of semantic roles in visual narrative. Cognitive Psychology, 67(3). 73-97. https://doi.org/10.1016/j. cogpsych.2013.07.002

Cutler, A., \& Foss, D. J. (1977). On the role of sentence stress in sentence processing. Language and Speech, 20(1), 1-10. https://doi.org/10.1177/002383097702000101

Cutler, A., Dahan, D., \& van Donselaar, W. (1997). Prosody in the comprehension of spoken language: A literature review. Language and Speech, 40(2), 141-201. https://doi.org/10.1177/002383099704000203

Dékány, É. (2017). The position of case markers relative to possessive agreement: Variation within Hungarian. Natural Language \& Linguist Theory, 36(2), 365-400. https://doi.org/10.1007/s11049-017-9379-7

Dryer, M. S. (2013). Position of case affixes. In M. S. Dryer \& M. Haspelmath (Eds.) The world atlas of language structures online. Max Planck Institute for Evolutionary Anthropology. http://wals.info/chapter $/ 51$

Du Bois, J. W. (2003). Discourse and grammar. In M. Tomasselo (Ed.), The new psychology of language: Cognitive and functional approaches to language structure (pp. 47-87). Lawrence Erlbaum.

Eady, S. J., Cooper, W. E., Kloouda, G. V., Mueller, P. R., \& Lotts, D. W. (1986). Acoustical characteristics of sentential focus: Narrow vs. broad and single vs. dual focus environments. Language and Speech, 29(3), 233-251. https://doi.org/10.1177/002383098602900304

É. Kiss, K. (1998). Identificational versus information focus. Language, 74(2), 245-273. https://doi. org/10.2307/417867

É. Kiss, K. (2008). Free word order, (non-)configurationality, and phases. Linguistic Inquiry, 39(3), 441-474. https://doi.org/10.1162/ling.2008.39.3.441

Erdocia, K., Laka, I., Mestres-Missé, A., \& Rodriguez-Fornells, A. (2009). Syntactic complexity and ambiguity resolution in a free word order language: Behavioural and electrophysiological evidences from Basque. Brain and Language, 109(1), 1-17. https://doi.org/10.1016/j.band1.2008.12.003

Féry, C. (2017). Intonation and prosodic structure. Cambridge University Press.

Féry, C., \& Kügler, F. (2008). Pitch accent scaling on given, new and focused constituents in German. Journal of Phonetics, 36(4), 680-703. https://doi.org/10.1016/j.wocn.2008.05.001 
Fodor, J. D. (1998). Learning to parse? Journal of Psycholinguistic Research, 27(2), 285-319. https://doi. org/10.1023/A:1023258301588

Genzel, S., Ishihara, S., \& Surányi, B. (2015). The prosodic expression of focus, contrast and givenness: A production study of Hungarian. Lingua, 165(Part B), 183-204. https://doi.org/10.1016/j.lingua.2014.07.010

Grice, M., Baumann, S., \& Jagdfeld, N. (2007). Evidence for tonal identity from peak scaling under pitch span variations. In Proceedings of the 16th International Congress of Phonetic Sciences (ICPhS), (pp. 977-980). https://citeseerx.ist.psu.edu/viewdoc/download?doi=10.1.1.558.5205\&rep=rep1\&typ $\mathrm{e}=\mathrm{pdf}$

Grünloh, T., Lieven, E., \& Tomasello, M. (2011). German children use prosody to identify participant roles in transitive sentences. Cognitive Linguistics, 22(2), 393-419. https://doi.org/10.1515/cogl.2011.015

H. Tóth, I., \& Patloka, R. (2009). A sokoldalú igekötő. Tudnivalók, gyakorlatok a magyar igekötős igék megismeréséhez [The versatile verb conjugator. Information and exercises for getting to know Hungarian verbs]. Robert Pejsa. [In Hungarian.]

Kaiser, E., \& Trueswell, J. C. (2004). The role of discourse context in the processing of a flexible word-order language. Cognition, 94(2), 113-147. https://doi.org/10.1016/j.cognition.2004.01.002

Káldi, T., \& Babarczy, A. (2018). Linguistic exhaustivity inference is context dependent: A visual-world eye-tracking study on Hungarian focus. Acta Linguistica Academica, 65(4), 547-595. https://doi. org/10.1556/2062.2018.65.4.2

Kamide, Y., Scheepers, C., \& Altmann, G. T. (2003). Integration of syntactic and semantic information in predictive processing: Cross-linguistic evidence from German and English. Journal of Psycholinguistic Research, 32(1), 37-55. https://doi.org/10.1023/A:1021933015362

Kas, B., Lukács, Á., \& Szentkuti-Kiss, K. (2016). A szórend és az esetjelölés szerepe specifikus nyelvi zavart mutató gyerekek mondatfeldolgozásában [The role of word order and case designation in sentence processing in children with specific language disorders]. In B. Kas (Ed.), "Szavad ne feledd!": Tanulmányok Bánréti Zoltán tiszteletére [“Remember your word!”: Studies in honor of Zoltán Bánréti] (pp. 367-381). MTA Nyelvtudományi Intézet. [In Hungarian.]

Kiefer, F. (2006). Alaktan [relic]. In F. Kiefer (Ed.), A magyar nyelv kézikönyve [Handbook of the Hungarian language] (pp. 185-204). Akadémiai Kiadó. [In Hungarian.]

Knoeferle, P, Crocker, M. W., Scheepers, C., \& Pickering, M. J. (2005). The influence of the immediate visual context on incremental thematic role-assignment: Evidence from eye movements in depicted events. Cognition, 95(1), 95-127. https://doi.org/10.1016/j.cognition.2004.03.002

Kröger, J. M. (2019). Real-time thematic role assignment in children and adults: The influence of case marking, prosody, and visual cues. $\mathrm{PhD}$ dissertation, Bielefeld University, Germany.

Kröger, J. M., Münster, K., \& Knoeferle, P. (2017). The influence of prosody and case marking on thematic role assignment in ambiguous action scenes: Adults versus children. In Proceedings of the 39th Annual Meeting of the Cognitive Science Society, (pp. 2463-2468). https://cogsci.mindmodeling.org/2017/ papers/0468/paper0468.pdf

Ladd, D. R. (2008). Intonational phonology (2nd ed.). Cambridge University Press.

Lambrecht, K. (2000). When subjects behave like objects: An analysis of the merging of S and $\mathrm{O}$ in sentencefocus constructions across languages. Studies in Language, 24(3), 611-682. https://doi.org/10.1075/ sl.24.3.06lam

Longenbaugh, N., \& Polinsky, M. (2016). Experimental approaches to ergative languages. In J. Coon, D. Massam, \& L. D. Travis (Eds.), The Oxford handbook of ergativity (pp. 709-736). Oxford University Press.

Mack, J. E., Ji, W., \& Thompson, C. K. (2013). Effects of verb meaning on lexical integration in agrammatic aphasia: Evidence from eyetracking. Journal of Neurolinguistics, 26(6), 619-636. https://doi. org/10.1016/j.jneuroling.2013.04.002

MacWhinney, B., \& Pléh, Cs. (1997). Double agreement: Role identification in Hungarian. Language and Cognitive Processes, 12(1), 67-102. https://doi.org/10.1080/016909697386916

MacWhinney, B., Bates, E., \& Kliegl, R. (1984). Cue validity and sentence interpretation in English, German, and Italian. Journal of Verbal Learning and Verbal Behavior, 23(2), 127-150. https://doi.org/10.1016/ S0022-5371(84)90093-8 
MacWhinney, B., Pléh, Cs., \& Bates, E. (1985). The development of sentence interpretation in Hungarian. Cognitive Psychology, 17(2), 178-209. https://doi.org/10.1016/0010-0285(85)90007-6

Mády, K. (2012). Deaccentuation in Hungarian and its logical background. In Proceedings of the 6th Speech Prosody Conference, Shanghai, China (pp. 310-313). http://real.mtak.hu/8770/1/sp2012 submission_168.pdf

Mády, K. (2015). Prosodic (Non-) Realisation of Broad, Narrow and Contrastive Focus in Hungarian: A Production and a Perception Study. In Sixteenth Annual Conference of the International Speech Communication Association (pp. 948-952). Dresden, Germany. https://core.ac.uk/download/pdf/42942162.pdf

McCullagh, P., \& Nelder, J. (1989). Generalized linear models. Chapman and Hall.

Mirman, D. (2014). Growth curve analysis and visualization using $R$. Taylor and Francis.

Münster, K. (2016). Effects of emotional facial expressions and depicted actions on situated language processing across the lifespan. PhD dissertation, University of Bielefeld, Bielefeld, Germany.

Nolan, F. (2003). Intonational equivalence: An experimental evaluation of pitch scales. In Proceedings of the 15th International Congress of Phonetic Sciences (pp. 771-774). https://www.internationalphoneticassociation.org/icphs-proceedings/ICPhS2003/papers/p15_0771.pdf

Onea, E., \& Beaver, D. (2011). Hungarian focus is not exhausted. In Proceedings of Semantics and Linguistic Theory, 19 (pp. 342-359). https://doi.org/10.3765/salt.v19i0.2524

Oravecz, Cs., Váradi, T., \& Sass, B. (2014). The Hungarian Gigaword Corpus. In Proceedings of LREC 2014 (pp. 1719-1723). http://www.lrec-conf.org/proceedings/lrec2014/pdf/681_Paper.pdf

Pléh, Cs. (1981). The role of word order in the sentence interpretation of Hungarian children. Folia Linguistica, 15(3-4), 331-343. https://doi.org/10.1515/flin.1981.15.3-4.331

Raaijmakers, J. G. W., Schrijnemakers, J. M. C., \& Gremmen, F. (1999). How to deal with "The languageas-fixed effect fallacy": Common misconceptions and alternative solutions. Journal of Memory and Language, 41(3), 416-426. https://doi.org/10.1006/jmla.1999.2650

$\mathrm{R}$ Core Team (2020). $R$ : A language and environment for statistical computing. R Foundation for Statistical Computing. https://www.R-project.org/

Read, C., Kraak, A., \& Boves, L. (1980). The interpretation of ambiguous who-questions in Dutch: The effect of intonation. In W. Zonneveld \& F. Weerman (Eds.), Linguistics in the Netherlands 1977-1979 (pp. 389-410). Foris.

Rounds, C. (2001). Hungarian: An essential grammar. Routledge.

Sauppe, S. (2016). Verbal semantics drives early anticipatory eye movements during the comprehension of verb-initial sentences. Frontiers in Psychology, 7(95), 1-13. https://doi.org/10.3389/fpsyg.2016.00095

Sedivy, J. C., Tanenhaus, M. K., Chambers, C. G., \& Carlson, G. N. (1999). Achieving incremental semantic interpretation through contextual representation. Cognition, 71(2), 109-147. https://doi.org/10.1016/ S0010-0277(99)00025-6

Snedeker, J., \& Trueswell, J. (2003). Using prosody to avoid ambiguity: Effects of speaker awareness and referential context. Journal of Memory and Language, 48(1), 103-130. https://doi.org/10.1016/S0749596X(02)00519-3

Surányi, B. (2010). Freedom of word order and domains for movement: A flexible syntax of Hungarian. PhD dissertation. Budapest, Hungary.

Szabolcsi, A. (1981). Compositionality in focus. Folia Linguistica, 15(1-2), 141-161. https://doi.org/10.1515/ flin.1981.15.1-2.141

Szendröi, K. (2001). Focus and the syntax-phonology interface. PhD dissertation. University College London, London, UK. https://www.ucl.ac.uk/ uczaksz/KSthesis_full.pdf

Szendröi, K. (2003). A stress-based approach to the syntax of Hungarian focus. The Linguistic Review, 20(1), 37-78. https://doi.org/10.1515/tlir.2003.002

Varga, L. (2002). Intonation and stress: Evidence from Hungarian. Palgrave Macmillan.

Weber, A., Braun, B., \& Crocker, M. W. (2006a). Finding referents in time: Eye-tracking evidence for the role of contrastive accents. Language and Speech, 49(3), 367-392. https://doi.org/10.1177/002383090 60490030301

Weber, A., Grice, M., \& Crocker, M. W. (2006b). The role of prosody in the interpretation of structural ambiguities: A study of anticipatory eye movements. Cognition, 99(2), B63-B72. https://doi.org/10.1016/j. cognition.2005.07.001 
Weskott, T. (2003). Information structure as a processing guide: The left periphery of German verb-second sentences and its interpretation in context. $\mathrm{PhD}$ dissertation. University of Leipzig, Germany.

Zhang, L., \& Knoeferle, P. (2012). Visual context effects on thematic role assignment in children versus adults: Evidence from eye tracking in German. In Proceedings of the Annual Meeting of the Cognitive Science Society (pp. 2593-2598). https://cogsci.mindmodeling.org/2012/papers/0450/paper0450.pdf

Appendix A. Target items (underlined = ambiguous character in the visual stimulus).

\begin{tabular}{|c|c|c|c|}
\hline Item & Order & Hungarian & Translation \\
\hline \multirow[t]{3}{*}{ I } & SVO & A bogár tolja most a gilisztát. & The beetle pushes now the worm. \\
\hline & OVS & A bogarat tolja most a bika. & The bull pushes now the beetle. \\
\hline & XVS & A bogaram tolja most a bika. & The bull pushes now my beetle. \\
\hline \multirow[t]{3}{*}{2} & SVO & A madár eteti most a delfint. & The bird feeds now the dolphin. \\
\hline & OVS & 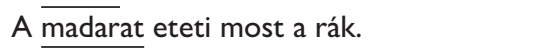 & The $\overline{c r a b}$ feeds now the bird. \\
\hline & XVS & A $\overline{\text { madaram }}$ eteti most a rák. & The crab feeds now my $\overline{\text { bird. }}$ \\
\hline \multirow[t]{3}{*}{3} & SVO & A hód fényképezi most a sünt. & The beaver photographs now the hedgehog. \\
\hline & OVs & A hódot fényképezi most a cápa. & The shark photographs now the beaver. \\
\hline & XVS & A hódom fényképezi most a cápa. & The shark photographs now my beaver. \\
\hline \multirow[t]{3}{*}{4} & SVO & A macska csiklandozza most a sast. & The cat tickles now the eagle. \\
\hline & OVS & A macskát csiklandozza most a hörcsög. & The hamster tickles now the cat. \\
\hline & XVS & A macskám csiklandozza most a hörcsög. & The hamster tickles now my cat. \\
\hline \multirow[t]{3}{*}{5} & SVO & A gólya koronázza hamarosan a koalát. & The stork crowns soon the koala. \\
\hline & OVs & A gólyát koronázza hamarosan a dínó. & The dinosaur crowns soon the stork. \\
\hline & XVS & A gólyám koronázza hamarosan a dínó. & The dinosaur crowns soon my stork. \\
\hline \multirow[t]{3}{*}{6} & SVO & A farkas üti hamarosan a tigrist. & The wolf beats soon the tiger. \\
\hline & OVs & A farkast üti hamarosan a kakas. & The rooster beats soon the wolf. \\
\hline & XVS & A $\overline{\text { farkasom üti hamarosan a kakas. }}$ & The rooster beats soon my wolf. \\
\hline \multirow[t]{3}{*}{7} & SVO & A szöcske vizsgálja hamarosan a bikát. & The grasshoper examines soon the bull. \\
\hline & OVs & A szöcskét vizsgálja hamarosan a delfin. & The dolphin examines soon the grasshoper. \\
\hline & XVS & A szöcském vizsgálja hamarosan a delfin. & The dolphin examines soon the grasshoper. \\
\hline \multirow[t]{3}{*}{8} & SVO & A bogár fröcsköli hamarosan a cápát. & The beetle splatters soon the dolphin. \\
\hline & OVS & A bogarat fröcsköli hamarosan a kukac. & The worm splatters soon the beetle. \\
\hline & XVS & A bogaram fröcsköli hamarosan a kukac. & The worm splatters soon my beetle. \\
\hline \multirow[t]{3}{*}{9} & SVO & A madár sprézi éppen a hörcsögöt. & The bird sprays at the moment the hamster. \\
\hline & OVS & A madarat sprézi éppen a koala. & The koala sprays at the moment the bird. \\
\hline & XVS & A madaram sprézi éppen a koala. & The koala sprays at the moment my bird. \\
\hline \multirow[t]{3}{*}{10} & SVO & A hód bűvöli éppen a rákot. & The beaver charms at the moment the crab. \\
\hline & OVS & A hódot bűvöli éppen a sas. & The eagle charms at the moment the beaver. \\
\hline & XVS & A hódom búvöli éppen a sas. & The eagle charms at the moment my $\overline{\text { beaver. }}$ \\
\hline \multirow[t]{3}{*}{11} & SVO & 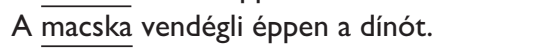 & The cat dines at the moment the dinosaur. \\
\hline & OVs & A macskát vendégli éppen a sün. & The hedgehog dines at the moment the cat. \\
\hline & XVS & A macskám vendégli éppen a sün. & The hedgehog dines at the moment my $\overline{c a t}$. \\
\hline \multirow[t]{3}{*}{12} & SVO & A gólya ajándékozza éppen a kakast. & The stork gifts at the moment the rooster. \\
\hline & OVs & A gólyát ajándékozza éppen a tigris. & The tiger gifts at the moment the stork. \\
\hline & XVS & A gólyám ajándékozza éppen a tigris. & The tiger gifts at the moment my stork. \\
\hline \multirow[t]{3}{*}{13} & SVO & A farkas kínálja rögtön a pingvint. & The wolf offers right away the pinguin. \\
\hline & OVs & A farkast kínálja rögtön a hattyú. & The swan offers right away the wolf. \\
\hline & XVS & A farkasom kínálja rögtön a hattyú. & The swan offers right away my wolf. \\
\hline
\end{tabular}


Appendix A. (Continued)

\begin{tabular}{|c|c|c|c|}
\hline Item & Order & Hungarian & Translation \\
\hline \multirow[t]{3}{*}{14} & sVO & A béka célozza rögtön a kutyát. & The frog targets right away the dog. \\
\hline & OVS & A békát célozza rögtön a gepárd. & The cheetah targets right away the frog. \\
\hline & XVS & A békám célozza rögtön a gepárd. & The cheetah targets right away my frog. \\
\hline \multirow[t]{3}{*}{15} & SVO & 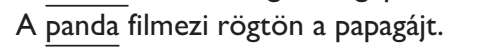 & The panda films right away the parrot. \\
\hline & OVS & A pandát filmezi rögtön a liba. & The goose films right away the panda. \\
\hline & XVS & A pandám filmezi rögtön a liba. & The goose films right away my panda. \\
\hline \multirow[t]{3}{*}{16} & SVO & A polip fésüli rögtön a szamarat. & The octopus combs right away the donkey. \\
\hline & OVS & A polipot fésüli rögtön a varjú. & The crow combs right away the octopus. \\
\hline & XVS & A polipom fésüli rögtön a varjú. & The crow combs right away my $\overline{\text { octopus. }}$ \\
\hline \multirow[t]{3}{*}{17} & SVO & A fóka szárítja mindjárt halat. & The sea calf dries very soon the fish. \\
\hline & OVS & A fókát szárítja mindjárt a madár. & The bird dries very soon the sea calf. \\
\hline & XVS & A fókám szárítja mindjárt a madár. & The bird dries very soon my sea calf. \\
\hline \multirow[t]{3}{*}{18} & SVO & A róka csókolja mindjárt a lepkét. & The fox kisses very soon the butterfly. \\
\hline & OVs & A rókát csókolja mindjárt a vakond. & The mole kisses very soon the fox. \\
\hline & XVS & A rókám csókolja mindjárt a vakond. & The mole kisses very soon my fox. \\
\hline \multirow[t]{3}{*}{19} & SVO & A béka nézi mindjárt a libát. & The frog watches very soon the goose. \\
\hline & OVS & A békát nézi mindjárt a lepke. & The butterfly watches very soon the frog. \\
\hline & XVS & A békám nézi mindjárt a lepke. & The butterfly watches very soon my frog. \\
\hline \multirow[t]{3}{*}{20} & SVO & A szöcske kérdi mindjárt a hattyút. & The grasshopper asks very soon the swan. \\
\hline & OVs & A szöcskét kérdi mindjárt a kutya. & The dog asks very soon the grasshopper. \\
\hline & XVS & A szöcském kérdi mindjárt a kutya. & The dog asks very soon my grasshopper. \\
\hline \multirow[t]{3}{*}{21} & SVO & A panda festi azonnal a verebet. & The panda paints immediately the sparrow. \\
\hline & OVS & A pandát festi azonnal a hal. & The fish paints immediately the panda. \\
\hline & $\mathrm{XVS}$ & A pandám festi azonnal a hal. & The fish paints immediately my panda. \\
\hline \multirow[t]{3}{*}{22} & SVO & A fóka védi azonnal a vakondot. & The sea calf protects immediately the mole. \\
\hline & OVs & A fókát védi azonnal a papagáj. & The parrot protects immediately the sea calf. \\
\hline & $\mathrm{XVS}$ & A fókám védi azonnal a papagáj. & The parrot protects immediately my sea calf. \\
\hline \multirow[t]{3}{*}{23} & SVO & A $\overline{\text { róka mossa azonnal a varjút. }}$ & The fox bathes immediately the crow. \\
\hline & OVs & A rókát mossa azonnal a pingvin. & 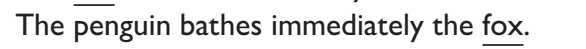 \\
\hline & XVS & A rókám mossa azonnal a pingvin. & The penguin bathes immediately my fox. \\
\hline \multirow[t]{3}{*}{24} & SVO & A polip rajzolja azonnal a gepárdot. & The octopus draws immediately the cheetah. \\
\hline & OVs & A polipot rajzolja azonnal a szamár. & The donkey draws immediately the octopus. \\
\hline & XVS & A polipom rajzolja azonnal a szamár. & The donkey draws immediately my octopus. \\
\hline
\end{tabular}

Appendix B. Mean durations of the stimuli.

\begin{tabular}{|c|c|c|c|c|c|c|c|c|}
\hline & \multicolumn{2}{|l|}{$\mathrm{NP}_{1}$} & \multicolumn{2}{|l|}{ V } & \multicolumn{2}{|c|}{ Adverb } & \multicolumn{2}{|l|}{$\mathrm{NP}_{2}$} \\
\hline & Mean & $\begin{array}{l}\text { STANDARD } \\
\text { ERROR (SE) }\end{array}$ & Mean & $S E$ & Mean & $S E$ & Mean & $S E$ \\
\hline SVO & I, 156 & 23 & 1,236 & 36.9 & 1062 & 25.3 & 869 & 22 \\
\hline s̄̄o & 1,219 & 21.9 & $\mathrm{I}, 228$ & 40.1 & 1052 & 23 & 881 & 19.4 \\
\hline ŌVS & 1,222 & 17.2 & 1,240 & 38.9 & 1045 & 22.5 & 719 & 21.5 \\
\hline ôvs & I,295 & 16.1 & $\mathrm{I}, 227$ & 40.2 & 1048 & 25.1 & 715 & 22.1 \\
\hline $\bar{X} \mathrm{~V}$ S & 1,233 & 12.7 & 1,233 & 39.2 & 1038 & 24.1 & 709 & 25.2 \\
\hline$X \bar{V} \bar{S}$ & $1,3 \mid 5$ & 14.1 & 1,237 & 42.4 & 1054 & 23.7 & 722 & 20.7 \\
\hline all & $\mathrm{I}, 240$ & 8.4 & $\mathrm{I}, 233$ & 15.9 & 1050 & 9.6 & 769 & 10.8 \\
\hline
\end{tabular}


Appendix C. Linear mixed-effects models of maximal fit

Table 5. Experiment I: fixations on role fillers.

\begin{tabular}{|c|c|c|c|c|c|c|c|c|c|}
\hline \multirow[t]{2}{*}{ Region } & \multirow[t]{2}{*}{ Effect } & \multicolumn{4}{|c|}{ Subjects } & \multicolumn{4}{|l|}{ Items } \\
\hline & & $\beta_{1}$ & $\begin{array}{l}\text { Standard } \\
\text { error }(S E)\end{array}$ & $t$ & $p(<)$ & $\beta_{2}$ & SE & $t$ & $p(<)$ \\
\hline \multirow{4}{*}{$\mathrm{NP}_{1}$} & Intercept & -0.463 & 0.084 & -5.532 & 0.001 & -0.4 & 0.039 & -10.248 & 0.001 \\
\hline & TIME & -0.716 & 0.055 & -13.128 & 0.001 & -.684 & 0.051 & -13.512 & 0.001 \\
\hline & StREsS & -0.053 & 0.029 & -1.829 & - & & & & \\
\hline & Time $\times$ STRESS & 0.113 & 0.055 & 2.08 & 0.05 & & & & \\
\hline \multirow[t]{4}{*}{ V } & Intercept & -0.556 & 0.101 & -5.517 & .001 & $-0.57 \mid$ & 0.057 & -10.015 & 0.001 \\
\hline & TIME & 0.612 & 0.051 & 12.058 & 0.001 & 0.615 & 0.051 & 12.053 & 0.001 \\
\hline & CASE & 0.185 & 0.048 & 3.847 & 0.001 & 0.194 & 0.042 & 4.617 & 0.001 \\
\hline & Time $\times$ CASE & 0.118 & 0.051 & 2.324 & 0.05 & & & & \\
\hline \multirow[t]{2}{*}{ Adverb } & Intercept & 0.05 & 0.111 & .446 & - & 0.079 & 0.06 & 1.32 & - \\
\hline & CASE & 0.215 & 0.044 & 4.898 & 0.001 & 0.183 & 0.055 & 3.346 & 0.01 \\
\hline \multirow[t]{5}{*}{$\mathrm{NP}_{2}$} & Intercept & 0.422 & 0.129 & 3.268 & 0.01 & 0.342 & 0.046 & 7.411 & 0.001 \\
\hline & TIME & & & & & 0.095 & 0.089 & 1.074 & - \\
\hline & CASE & 0.256 & 0.053 & 4.796 & 0.001 & 0.209 & 0.048 & 4.324 & 0.001 \\
\hline & StRESS & & & & & -0.053 & 0.048 & -1.101 & - \\
\hline & TIMEXSTRESS & & & & & -0.192 & 0.089 & -2.174 & 0.05 \\
\hline
\end{tabular}

Table 6. Experiment I: fixations on the agent.

\begin{tabular}{|c|c|c|c|c|c|c|c|c|c|}
\hline \multirow[t]{2}{*}{ Region } & \multirow[t]{2}{*}{ Effect } & \multicolumn{4}{|c|}{ Subjects } & \multicolumn{4}{|l|}{ Items } \\
\hline & & $\beta_{1}$ & $\begin{array}{l}\text { Standard } \\
\text { error (SE) }\end{array}$ & $t$ & $p(<)$ & $\beta_{2}$ & SE & $t$ & $p(<)$ \\
\hline \multirow[t]{8}{*}{$\mathrm{NP}_{1}$} & Intercept & 0.016 & 0.042 & 0.369 & - & 0.018 & 0.046 & 0.388 & - \\
\hline & Time & -0.216 & 0.063 & $-3.41 I$ & 0.001 & -0.18 & 0.063 & -2.848 & 0.01 \\
\hline & CASE & 0.017 & 0.054 & 0.326 & - & 0.031 & 0.06 & 0.511 & - \\
\hline & StRESS & 0.057 & 0.045 & 1.248 & - & 0.032 & 0.064 & 0.5 & - \\
\hline & TIME $\times$ CASE & -0.082 & 0.063 & -1.304 & - & -0.081 & 0.063 & -1.277 & - \\
\hline & Time $\times$ StRess & -0.124 & 0.063 & -1.963 & 0.05 & -0.121 & 0.063 & -1.919 & - \\
\hline & Case $\times$ Stress & 0.106 & 0.046 & 2.319 & 0.05 & 0.088 & 0.051 & $\mathrm{I} .727$ & - \\
\hline & Time $\times$ CASE $\times$ Stress & 0.208 & 0.063 & 3.283 & 0.001 & 0.203 & 0.063 & 3.218 & 0.001 \\
\hline \multirow[t]{4}{*}{ V } & Intercept & 0.097 & 0.071 & 1.368 & - & 0.08 & 0.066 & 1.219 & - \\
\hline & TIME & 0.203 & 0.066 & 3.078 & 0.01 & 0.141 & 0.063 & 2.246 & 0.05 \\
\hline & CAse & 0.222 & 0.093 & 2.4 & 0.05 & 0.28 & 0.077 & 3.617 & 0.001 \\
\hline & Time $\times$ CASE & 0.332 & 0.066 & 5.019 & 0.001 & 0.346 & 0.063 & 5.513 & 0.001 \\
\hline \multirow[t]{8}{*}{ Adverb } & Intercept & 0.163 & 0.065 & 2.527 & 0.05 & 0.128 & 0.069 & 1.849 & - \\
\hline & Time & 0.064 & 0.069 & 0.921 & - & 0.047 & 0.07 & 0.669 & - \\
\hline & CASE & 0.551 & 0.14 & 3.938 & 0.001 & 0.587 & 0.091 & 6.436 & 0.001 \\
\hline & StRESS & 0.092 & 0.046 & 2.002 & - & 0.107 & 0.071 & 1.508 & - \\
\hline & Time $\times$ CASE & -0.146 & 0.069 & -02.115 & 0.05 & -0.018 & 0.07 & $-0.26 I$ & - \\
\hline & TIME $\times$ STRESS & 0.289 & 0.069 & 4.18 & 0.001 & 0.292 & 0.07 & 4.147 & 0.001 \\
\hline & Case $\times$ Stress & 0.097 & 0.06 & 1.611 & - & 0.094 & 0.064 & 1.468 & - \\
\hline & TIME $\times$ CASE $\times$ Stress & -0.294 & 0.069 & -4.254 & 0.001 & -0.281 & 0.07 & -3.992 & 0.001 \\
\hline
\end{tabular}


Table 6. (Continued)

\begin{tabular}{|c|c|c|c|c|c|c|c|c|c|}
\hline \multirow[t]{2}{*}{ Region } & \multirow[t]{2}{*}{ Effect } & \multicolumn{4}{|l|}{ Subjects } & \multicolumn{4}{|l|}{ Items } \\
\hline & & $\beta_{1}$ & $\begin{array}{l}\text { Standard } \\
\text { error }(S E)\end{array}$ & $t$ & $p(<)$ & $\beta_{2}$ & $S E$ & $t$ & $p(<)$ \\
\hline \multirow{6}{*}{$\mathrm{NP}_{2}$} & Intercept & 0.146 & 0.079 & 1.852 & - & 0.119 & 0.081 & 1.469 & - \\
\hline & Time & -0.161 & 0.092 & -1.759 & - & -0.055 & 0.098 & -0.565 & - \\
\hline & CASE & 0.69 & 0.16 & 4.316 & 0.001 & 0.735 & 0.111 & 6.644 & 0.001 \\
\hline & StRESS & -0.003 & 0.057 & -0.053 & - & -0.037 & 0.065 & -0.569 & - \\
\hline & TIME $\times$ CASE & 0.305 & 0.092 & 3.335 & 0.001 & 0.231 & 0.098 & 2.359 & 0.05 \\
\hline & TimeXSTRESS & -0.525 & 0.091 & -5.74 & 0.001 & -0.365 & 0.098 & -3.73 & 0.001 \\
\hline
\end{tabular}

Table 7. Experiment 2: fixations on role fillers.

\begin{tabular}{|c|c|c|c|c|c|c|c|c|c|}
\hline \multirow[t]{2}{*}{ Region } & \multirow[t]{2}{*}{ Effect } & \multicolumn{4}{|c|}{ Subjects } & \multicolumn{4}{|l|}{ Items } \\
\hline & & $\beta_{1}$ & $\begin{array}{l}\text { Standard } \\
\text { error (SE) }\end{array}$ & $t$ & $p(<)$ & $\beta_{2}$ & SE & $t$ & $p(<)$ \\
\hline \multirow[t]{4}{*}{$\mathrm{NP}_{\text {, }}$} & Intercept & -0.58 & 0.064 & -9.04 & 0.001 & -0.566 & 0.051 & -11.174 & 0.001 \\
\hline & TIME & -1.182 & 0.055 & -21.595 & 0.001 & -1.142 & 0.05 & -22.648 & 0.001 \\
\hline & StRESS & -0.02 & 0.026 & -0.784 & - & 0.013 & 0.034 & 0.391 & - \\
\hline & TIMEXSTRESS & 0.114 & 0.055 & 2.081 & 0.05 & 0.107 & 0.05 & 2.115 & 0.05 \\
\hline \multirow[t]{8}{*}{ V } & Intercept & -0.767 & 0.11 & -6.979 & 0.001 & -0.748 & 0.057 & -13.167 & 0.001 \\
\hline & TIME & 0.707 & 0.05 & 14.216 & 0.001 & 0.71 & 0.048 & 14.812 & 0.001 \\
\hline & CASE & 0.197 & 0.039 & 5.002 & 0.001 & 0.179 & 0.035 & 5.073 & 0.001 \\
\hline & STRESS & 0.018 & 0.043 & 0.412 & - & 0.017 & 0.04 & 0.434 & - \\
\hline & TIME $\times$ CASE & 0.13 & 0.05 & 2.606 & 0.01 & 0.134 & 0.048 & 2.795 & 0.01 \\
\hline & TIMEXSTRESS & & & & & 0.06 & 0.048 & I.244 & - \\
\hline & Case $\times$ Stress & 0.099 & 0.037 & 2.698 & 0.05 & 0.077 & 0.04 & 1.901 & - \\
\hline & Time $\times$ CASE $\times$ STREsS & & & & & 0.102 & 0.048 & 2.14 & 0.05 \\
\hline \multirow[t]{2}{*}{ Adverb } & Intercept & -0.072 & 0.1 & -0.715 & - & -0.11 & 0.058 & -1.895 & - \\
\hline & CASE & 0.201 & 0.042 & 4.837 & 0.001 & 0.2 & 0.045 & 4.461 & 0.001 \\
\hline \multirow[t]{8}{*}{$\mathrm{NP}_{2}$} & Intercept & 0.196 & 0.117 & 1.675 & - & 0.214 & $0.05 I$ & 4.206 & 0.001 \\
\hline & TIME & 0.914 & 0.096 & 9.562 & 0.001 & 0.886 & 0.092 & 9.662 & 0.001 \\
\hline & CAse & 0.163 & 0.064 & 2.536 & 0.05 & 0.173 & 0.064 & 2.716 & 0.05 \\
\hline & StRESS & -0.092 & 0.055 & -1.685 & - & -0.089 & 0.055 & -1.612 & - \\
\hline & TIME $\times$ CASE & -0.11 & 0.096 & -1.155 & - & -0.155 & 0.092 & -1.695 & - \\
\hline & Time $\times$ STRESS & -0.25 & 0.095 & -2.619 & 0.01 & -0.271 & 0.092 & -2.955 & 0.01 \\
\hline & CAse $\times$ Stress & 0.015 & 0.047 & 0.311 & - & 0.021 & 0.067 & 0.313 & - \\
\hline & Time $\times$ CASE $\times$ STREsS & 0.203 & 0.095 & 2.13 & 0.05 & 0.228 & 0.092 & 2.489 & 0.05 \\
\hline
\end{tabular}


Table 8. Experiment 2: fixations to the agent.

\begin{tabular}{|c|c|c|c|c|c|c|c|c|c|}
\hline \multirow[t]{2}{*}{ Region } & \multirow[t]{2}{*}{ Effect } & \multicolumn{4}{|l|}{ Subjects } & \multicolumn{4}{|l|}{ Items } \\
\hline & & $\beta_{1}$ & $\begin{array}{l}\text { Standard } \\
\text { error }(S E)\end{array}$ & $t$ & $p(<)$ & $\beta_{2}$ & SE & $t$ & $p(<)$ \\
\hline \multirow{4}{*}{$\mathrm{NP}_{1}$} & Intercept & 0.198 & 0.068 & 2.907 & 0.01 & 0.174 & 0.068 & 2.566 & 0.05 \\
\hline & Time & -0.017 & 0.067 & -0.254 & - & 0.018 & 0.069 & 0.262 & - \\
\hline & CASE & -0.017 & 0.049 & -0.349 & - & 0.007 & 0.072 & 0.095 & - \\
\hline & TIME $\times$ CASE & 0.139 & 0.067 & 2.08 & 0.05 & 0.137 & 0.069 & 2.001 & 0.05 \\
\hline \multirow[t]{8}{*}{ V } & Intercept & 0.195 & 0.085 & 2.297 & 0.05 & 0.207 & 0.11 & 1.882 & - \\
\hline & Time & -0.116 & 0.067 & -1.739 & - & -0.072 & 0.066 & -1.088 & - \\
\hline & CASE & 0.268 & 0.072 & 3.703 & 0.001 & 0.203 & 0.072 & 2.817 & 0.01 \\
\hline & STRESS & & & & & -0.025 & 0.079 & -0.323 & - \\
\hline & TIME $\times$ CASE & 0.321 & 0.067 & 0.817 & 0.001 & 0.346 & 0.066 & 5.246 & 0.001 \\
\hline & TIMEXSTRESS & & & & & 0.073 & 0.066 & 1.109 & - \\
\hline & CASE $\times$ Stress & & & & & -0.013 & 0.057 & -0.229 & - \\
\hline & Time $\times$ Case $\times$ Stress & & & & & 0.16 & 0.066 & 2.43 & 0.05 \\
\hline \multirow[t]{8}{*}{ Adverb } & Intercept & 0.223 & 0.087 & 2.574 & 0.05 & 0.217 & 0.077 & 2.832 & 0.01 \\
\hline & TIME & 0.085 & 0.071 & 1.205 & - & 0.084 & 0.071 & 1.184 & - \\
\hline & CASE & 0.477 & 0.075 & 6.336 & 0.001 & 0.463 & 0.076 & 6.113 & 0.001 \\
\hline & StRESS & -0.069 & 0.074 & -0.941 & - & -0.064 & 0.068 & -0.953 & - \\
\hline & TIME $\times$ CASE & & & & & 0.037 & 0.071 & 0.523 & - \\
\hline & TIME $\times$ StRESS & -0.16 & 0.07 & -2.273 & 0.05 & -0.274 & 0.071 & -3.879 & 0.001 \\
\hline & CAse $\times$ Stress & & & & & -0.046 & 0.073 & -0.63 & - \\
\hline & TIME $\times$ CASE $\times$ STRESS & & & & & 0.233 & 0.071 & 3.308 & 0.001 \\
\hline \multirow{4}{*}{$\mathrm{NP}_{2}$} & Intercept & 0.432 & 0.094 & 4.606 & 0.001 & 0.404 & 0.096 & 4.203 & 0.001 \\
\hline & Time & 0.557 & 0.094 & 5.921 & 0.001 & 0.636 & 0.102 & 6.264 & 0.001 \\
\hline & CASE & 0.639 & 0.068 & 9.402 & 0.001 & 0.633 & 0.08 & 7.926 & 0.001 \\
\hline & TIME $\times$ CASE & -0.189 & 0.094 & -2.01 & 0.05 & & & & \\
\hline
\end{tabular}

